\title{
Facile synthesis, biological evaluation and molecular docking studies of novel substituted azole derivatives
}

\author{
A running title: Synthesis, biological evaluation and molecular docking studies
}

Muhammad Rafiq ${ }^{\mathrm{a}, \mathrm{b}}$, Muhammad Saleem ${ }^{\mathrm{c}, \mathrm{d}}$, Farukh Jabeen ${ }^{\mathrm{e}, \mathrm{f}}$, Muhammad Hanif ${ }^{\mathrm{g}}$, Sung-Yum Seo ${ }^{\mathrm{a}}$, Sung Kwon Kang $^{\text {h }}$, Ki Hwan Lee ${ }^{\mathrm{c}, *}$

${ }^{a}$ Department of Biology, Kongju National University, Gongju, Chungnam 32588, Republic of Korea

${ }^{b}$ Department of Biochemistry and Biotechnology (Baghdad-ul-Jadeed Campus), The Islamia University of Bahawalpur 63100, Pakistan

${ }^{c}$ Department of Chemistry, Kongiu National University, Gongju, Chungnam 32588, Republic of Korea

${ }^{d}$ Department of Chemistry, University of Sargodha, Sub-campus Mianwali, Pakistan

${ }^{e}$ Florida Center of Heterocyclic Compounds, University of Florida, Gainesville, Fl, 32601, USA

${ }^{f}$ Center for Computationally Assisted Science and Technology, North Dakota State University, Fargo, ND, 58102, USA

${ }^{g}$ Department of Chemistry, GC University Faisalabad (sub campus layyah), Pakistan

${ }^{h}$ Department of Chemistry Chungnam National University Daejeon 34134, Republic of Korea

*Corresponding author. Fax: +82-41-856-8613; E-mail address: khlee@kongju.ac.kr

\begin{abstract}
In this study, we synthesized the series of novel azole derivatives and evaluated for enzyme inhibition assays, corresponding kinetic analysis and molecular modeling. Among the investigated bioassays, the oxadiazole derivatives $\mathbf{4} \mathbf{a}-\mathbf{k}$ were found potent $\alpha$-glucosidase inhibitors while the Schiff base derivatives $\mathbf{7 a - k}$ exhibited considerable potential toward urease inhibition. The inhibition kinetics for the most active compounds were analyzed by the Lineweaver-Burk plots to investigate the possible binding modes of the synthesized compounds toward the tested proteins. Moreover, the detailed docking studies were performed on the synthesized library of $\mathbf{4 a - k}$ and 7a-k to study the molecular interaction and binding mode in the active site of the modeled yeast $\alpha$-glucosidase and Jack Bean Urease, respectively. It could be inferred from docking results that theoretical studies are in close agreement to that of the experimental results. The structure of one of the compound $7 \mathbf{k}$ was characterized by the single crystal X-ray diffraction analysis in order to find out the predominant conformation of the molecules.
\end{abstract}

Keywords: triazole Schiff bases; biological evaluation; kinetic analysis; molecular modeling; single crystal XRD.

\section{Introduction}

Development of new therapeutic agents utilizing natural or non-toxic precursor is one of the fundamental goals in medicinal chemistry for the design and development of novel drugs. The five-membered heteroaromatic rings are important building blocks of a wide range of biologically active molecules and have become a substantial construction motif in drug discovery [1,2]. The 1,3,4-oxadiazoles are influential heterocyclic systems in the field of synthetic, medicinal and materials chemistry due to their remarkable biological and pharmacological properties such as anti-bacterial [3,4], antimicrobials [5], antifungal [6], anti-oxidant [7], anticancer [8], anticonvulsants [9], antiproliferative [10], anti-inflammatory [11] and insecticidal activities [12], as well as conspicuous enzyme inhibitions against varieties of enzymes including superoxide dismutase [13], gluconeogenesis [14], telomerase [15], $\alpha$-glucosidase [16], $\alpha$-amylase [17], histone deacetylase [18] and thymidine phosphorylase [19]. The substituted 
oxadiazole derivative also have attracted attention in photochemistry for the development of optical sensor, staining agent and storage material due to their consequential light harvesting potential [20,21].

Guo et al. [22] patented the heterocyclic skeleton containing oxadiazole nucleus a (Fig. 1) as effective for type 2 diabetes Mellitus, and of conditions that are often associated with this disease, including hyperglycemia, insulin resistance, obesity, lipid disorders, and hypertension. Shingalapur et al. [23], reported the excellent anti-diabetic potential for the 1,3,4-oxadiazoles derivatives b (Fig. 1). Recently, Nazreen et al. [24] and Kashtoh et al. [25] found 1,3,4-oxadiazole containing heterocycles $\mathbf{c}, \mathbf{d}$ and $\mathbf{e}$ (Fig. 1) exhibiting significant blood glucose lowering effect and $\alpha$-glucosidase inhibition efficacy comparable with that of reference standard. Keeping in view the recent developed structure activity relationship of 1,3,4-oxadiazole compounds, we have synthesized a series of eleven oxadiazole derivatives $\mathbf{4 a - k}$ and evaluated their $\alpha$-glucosidase inhibition activity by spectrophotometric methods along with the kinetic analysis by Lineweaver-Burk plots.

Similarly, the 1,2,4-triazole containing compounds have been shown to exhibit a variety of interesting biological actions, including anti-cancer [25,26], anti-inflammatory [27], anti-diabetic [28], anti-malarial [29], antiproliferative [30], antimitotic, anti-vascular [31], anticonvulsant [32], anti-fungal and enzyme inhibition potential such as urease [33] and $\alpha$-fucosidase [34]. The alterations in chemical structure of substituted 1,2,4-triazoles strongly change their activities and affect their interaction with cells and tissues, thereby leading to different biological effects [35]. Schiff bases have been widely used in several fields of chemical production and scientific research as chelating agents, stabilizers, biologically active agents, analysis and catalytic reagents [36]. Schiff bases derived from various heterocycles were reported to possess diverse biological activities [37]. Alongside, the Schiff base containing 1,2,4-triazole nucleus have attracted great and growing interest in chemistry and biology for many years due to their facile synthesis and broad range of biological activities [38-41], including antitumor [40], antiviral [42], anti-bacterial [43] and corrosive inhibitor [44, 45].

Amtul et al. [46], reported a series of twenty five 1,2,4-triazole-3-thiones derivatives $\mathbf{f}$ (Fig. 2) exhibiting urease inhibition potential. Ibrar et al. [47] summarizes a library of triazole scaffold $\mathbf{g - m}$ (Fig. 2) as potent urease inhibitors. Recently, Mentese et al. [48] reported microwave assisted synthesis of relatively complex triazole derivatives $\mathbf{n}$ (Fig. 2) as urease inhibitors. Prompted by recent findings, the present study was undertaken to develop novel Schiff base derivatives containing 1,2,4-triazole nucleus and employed them against urease inhibition assay by spectrophotometric methods using thiourea as reference inhibitor alongside kinetic investigation to get mechanistic insight. The commendable urease inhibition potential was observed by the designed Schiff bases of 1,2,4-triazole in comparison to the previously reported isolated triazole based molecules o (Fig. 2) [49] or those Schiff base derivatives where there was no direct connection of imine bond with that of triazole skeleton e. g., p (Fig. 2) [50]. Moreover, the predominant conformational structures adopted by the compounds $7 \mathbf{a}-\mathbf{k}$ were checked out by growing the fine crystal of one of the compounds among the series with the subsequent characterization with the single crystal X-ray diffraction analysis.

\section{Fig. 1 and Fig. 2}

\section{Experimental}

\section{Substrate and reagents}

Phenyl, aryl and aralkyl carboxylic acids were purchased from Alfa Aesar and Aldrich. Ethanol, methanol, chloroform, water (Samchun Chemicals, Korea), $\mathrm{H}_{2} \mathrm{SO}_{4}, \mathrm{HCl}$ (Jin Chemical \& Pharmaceutical Co. Ltd., Korea) were used in these experiments. Urease from Jack bean (EC 3.5.1.5), $\alpha$-glucosidase from Saccharomyees Cerevisiae, 
(EC 3.2.1.2.0), thiourea, EDTA, sodium nitroprusside and active chloride, were purchased from Sigma Aldrich. All the reagents used for bioassays were of analytical grade.

\section{Instrumentations}

The reaction progress was monitored by thin layer chromatographic (TLC) analysis and the $\mathrm{R}_{f}$ values were determined by employing pre-coated silica gel aluminum plates, Kieselgel $60 \mathrm{~F}_{254}$ from Merck (Germany). TLC was visualized under a UV lamp (VL-4 LC, France). The melting points were determined on a Fisher Scientific (USA) melting point apparatus and are uncorrected. The FT-IR spectra were recorded in KBr pellets on a Shimadzu FTIR-8400S spectrometer (Kyoto, Japan). Proton and carbon nuclear magnetic resonance $\left({ }^{1} \mathrm{H}\right.$ NMR \& ${ }^{13} \mathrm{C}$ NMR) spectra were recorded on a Bruker Avance $400 \mathrm{MHz}$ spectrometer. The chemical shifts are reported as $\delta$ values in ppm downfield from the internal tetramethylsilane of the indicated organic solution. Peak multiplicities are expressed as follows: s, singlet; d, doublet and m, multiplet. Single crystal data was obtained by using Bruker SMART APEX II X-ray Diffractometer CCD equipped with Mo X-ray tube and graphite monochromator at the ambient temperature. The schematic representation of synthetic route adapted to obtained target compounds $\mathbf{4 a - k}$ and $\mathbf{7 a - k}$ are shown in Scheme 1.

\section{$\underline{\underline{\text { Scheme } 1}}$}

\section{Synthesis of aralkanoic acid hydrazides 3}

Aralkanoic acid chlorides 2 were synthesized by the reaction of aralkanoic acids 1 (1 mmol) in the presence of 1,2-dichloroethane $(12 \mathrm{~mL})$ solvent and phosphorous oxychloride $(0.4 \mathrm{~mL})$ as chlorinating agent under reflux for 3 $\mathrm{h}$. Then, the resulting solution was cooled to room temperature, and the solvent was removed under reduced pressure to afford aralkanoic acid chlorides 2, which was directly used in the next step without further purification. Aralkanoic acid chlorides 2 was dissolved in acetonitrile $(80 \mathrm{~mL})$, added drop wise to a solution containing hydrazine hydrate $(1 \mathrm{mmol})$, TEA $(0.5 \mathrm{~mL})$ and acetonitrile $(20 \mathrm{~mL})$ and allowed to reflux for $3 \mathrm{~h}$ with monitoring by TLC. After consumption of the starting material, the reaction mixture was cooled to room temperature. Evaporation of the solvent under reduced pressure yielded crude substituted aromatic acid hydrazides $\mathbf{3}$ as a white solid on cooling, which was purified by column chromatography and crystallized on methanol.

\section{Synthesis of 2,5-disubstituted-1,3,4-oxadiazoles 4a-k}

An equimolar mixture of aralkanoic acid hydrazides $\mathbf{3}$ and substituted aromatic acids were mixed in phosphorous oxychloride and heated under reflux at $107{ }^{\circ} \mathrm{C}$ for $3 \mathrm{~h}$. The reaction progress was monitored by thin layer chromatography. After consumption of the starting material; the reaction mixture was cooled to room temperature and poured into crushed ice which becomes precipitated. These precipitates was filtered, washed with cold water and diethyl ether, filtered and crystallized on methanol to get 2,5-disubstituted-1,3,4-oxadiazoles 4a-k. The product was purified with column chromatography.

\section{2,5-Bis(4-methoxybenzyl)-1,3,4-oxadiazole (4a)}

Off white solid; yield: $71 \%$; $\mathrm{R}_{f}: 0.64$ ( $n$-hexane : ethyl acetate, 8:2); FT-IR $\left(\mathrm{v} / \mathrm{cm}^{-1}\right): 3026\left(\mathrm{sp}^{2} \mathrm{CH}\right), 2945\left(\mathrm{sp}^{3} \mathrm{CH}\right)$, $1579(\mathrm{C}=\mathrm{N}), 1551,1498\left(\mathrm{C}=\mathrm{C}\right.$ of phenyl ring); ${ }^{1} \mathrm{H}$ NMR $\left(400 \mathrm{M} \mathrm{Hz}, \mathrm{DMSO}-d_{6}\right) \delta 7.19-7.00(\mathrm{~m}, 4 \mathrm{H}$, aromatic proton), 6.98-6.89 (m, $2 \mathrm{H}$, aromatic proton), 6.88-6.68 (m, $2 \mathrm{H}$, aromatic proton), 3.66 (s, $2 \mathrm{H}$, aliphatic $\mathrm{CH}_{2}$ ), 3.64 (s, 3H, methoxy proton), 3.60 (s, 2H, aliphatic $\left.\mathrm{CH}_{2}\right) ;{ }^{13} \mathrm{C}$ NMR (100 MHz, DMSO- $\left.d_{6}\right) \delta 158.4,155.1,149.3,147.0$, $130.0,127.6,125.8,120.5,114.1,120.0,56.1,55.9,31.5$. 


\section{2-(4-Fluorophenethyl)-5-(4-methoxybenzyl)-1,3,4-oxadiazole (4b)}

Brown solid; yield: 77 \%; Rf: 0.62 ( $n$-hexane : ethyl acetate, 8:2); FT-IR (v / $\left.\mathrm{cm}^{-1}\right): 3041\left(\mathrm{sp}^{2} \mathrm{CH}\right), 2947\left(\mathrm{sp}^{3} \mathrm{CH}\right)$, $1579(\mathrm{C}=\mathrm{N}), 1568,1478\left(\mathrm{C}=\mathrm{C}\right.$ of phenyl ring); ${ }^{1} \mathrm{H}$ NMR (400 M Hz, DMSO- $\left.d_{6}\right) \delta 7.35-7.31(\mathrm{~m}, 1 \mathrm{H}$, aromatic proton), 7.25-7.23 (m, 1H, aromatic proton), 7.03-7.01 (m, 1H, aromatic proton), 6.97-6.91 (m, 1H, aromatic proton), 6.88-6.81 (m, $2 \mathrm{H}$, aromatic proton), 6.78-6.73 (m, $2 \mathrm{H}$, aromatic proton), $3.69\left(\mathrm{t}, 2 \mathrm{H}\right.$, aliphatic $\left.\mathrm{CH}_{2}\right), 3.66(\mathrm{~s}$, $\left.3 \mathrm{H}, \mathrm{OCH}_{3}\right), 2.34\left(\mathrm{t}, 2 \mathrm{H}\right.$, aliphatic $\left.\mathrm{CH}_{2}\right) ;{ }^{13} \mathrm{C}$ NMR $\left(100 \mathrm{MHz}, \mathrm{DMSO}-d_{6}\right) \delta 158.4,154.9,146.7,139.2,133.2,130.1$, 129.6, 128.4, 127.4, 124.9, 114.1, 55.4, 31.6, 21.1.

\section{2-(3-Fluorophenethyl)-5-(4-methoxybenzyl)-1,3,4-oxadiazole (4c)}

Off white solid; yield: $76 \%$; $\mathrm{R}_{f}: 0.64$ (n-hexane : ethyl acetate, 8:2); FT-IR (v / $\left.\mathrm{cm}^{-1}\right): 3044\left(\mathrm{sp}^{2} \mathrm{CH}\right), 2947\left(\mathrm{sp}^{3} \mathrm{CH}\right)$, $1581(\mathrm{C}=\mathrm{N}), 1565,1514,1497\left(\mathrm{C}=\mathrm{C}\right.$ of phenyl ring); ${ }^{1} \mathrm{H}$ NMR (400 M Hz, DMSO- $\left.d_{6}\right) \delta 7.50-7.44(\mathrm{~m}, 1 \mathrm{H}$, aromatic proton), $7.31-7.27(\mathrm{~m}, 1 \mathrm{H}$, aromatic proton), 7.25-7.18 (m, 1H, aromatic proton), 7.12-7.10 (m, $1 \mathrm{H}$, aromatic proton), 6.90-6.85 (m, 2H, aromatic proton), 6.77-6.75 (m, $2 \mathrm{H}$, aromatic proton), $3.78\left(\mathrm{~s}, 2 \mathrm{H}\right.$, aliphatic $\left.\mathrm{CH}_{2}\right), 3.73(\mathrm{t}$, $2 \mathrm{H}, J=6.4 \mathrm{~Hz}$, aliphatic $\left.\mathrm{CH}_{2}\right), 3.72\left(\mathrm{~s}, 3 \mathrm{H}\right.$, aliphatic $\left.\mathrm{OCH}_{3}\right), 1.25\left(\mathrm{t}, 2 \mathrm{H}, J=7.2 \mathrm{~Hz}\right.$, aliphatic $\left.\mathrm{CH}_{2}\right)$; ${ }^{13} \mathrm{C} \mathrm{NMR}(100$ MHz, DMSO- $\left.d_{6}\right) \delta 161.1,158.4,155.6,154.6,153.8,146.4,131.3,130.8,129.0,128.0,124.1,116.0,55.4,31.6$, $29.2,14.9$.

\section{2-(2-Fluorophenethyl)-5-(4-methoxybenzyl)-1,3,4-oxadiazole (4d)}

Brown solid; yield: 77 \%; Rf: 0.60 ( $n$-hexane : ethyl acetate, 8:2); FT-IR (v / $\left.\mathrm{cm}^{-1}\right): 3055$ ( $\left.\mathrm{sp}^{2} \mathrm{CH}\right), 2936\left(\mathrm{sp}^{3} \mathrm{CH}\right)$, $1588(\mathrm{C}=\mathrm{N}), 1556,1533,1501\left(\mathrm{C}=\mathrm{C}\right.$ of phenyl ring); ${ }^{1} \mathrm{H}$ NMR $\left(400 \mathrm{M} \mathrm{Hz}, \mathrm{DMSO}-d_{6}\right) \delta 7.29-7.23(\mathrm{~m}, 1 \mathrm{H}$, aromatic proton), 7.14-7.00 (m, 4H, aromatic proton), 6.99-6.98 (m, 2H, aromatic proton), 6.82-6.80 (m, 2H, aromatic proton), $3.99\left(\mathrm{~s}, 2 \mathrm{H}\right.$, aliphatic $\left.\mathrm{CH}_{2}\right), 3.73\left(\mathrm{t}, 2 \mathrm{H}, J=6.4 \mathrm{~Hz}\right.$, aliphatic $\left.\mathrm{CH}_{2}\right), 3.68\left(\mathrm{~s}, 3 \mathrm{H}\right.$, aliphatic $\left.\mathrm{OCH}_{3}\right), 1.24(\mathrm{t}$, $2 \mathrm{H}, J=7.2 \mathrm{~Hz}$, aliphatic $\left.\mathrm{CH}_{2}\right) ;{ }^{13} \mathrm{C}$ NMR (100 MHz, DMSO-d 6 ) $\delta 158.2,154.1,146.7,139.4,133.2,130.9,129.6$, $128.4,127.4,124.9,114.1,55.4,31.6,29.2,14.9$.

\section{2-(4-Methoxybenzyl)-5-(2-methoxyphenethyl)-1,3,4-oxadiazole (4e)}

yellow solid; yield: $76 \%$; $\mathrm{R}_{f}$ : 0.65 ( $n$-hexane : ethyl acetate, 8:2); FT-IR (v / $\left.\mathrm{cm}^{-1}\right): 3045\left(\mathrm{sp}^{2} \mathrm{CH}\right), 2951\left(\mathrm{sp}^{3} \mathrm{CH}\right)$, $1584(\mathrm{C}=\mathrm{N}), 1556,1511,1494\left(\mathrm{C}=\mathrm{C}\right.$ of phenyl ring); ${ }^{1} \mathrm{H}$ NMR $\left(400 \mathrm{M} \mathrm{Hz}, \mathrm{DMSO}-d_{6}\right) \delta 7.48-7.22(\mathrm{~m}, 4 \mathrm{H}$, aromatic proton), 7.12-7.10 (m, $2 \mathrm{H}$, aromatic proton), 6.89-6.74 (m, $2 \mathrm{H}$, aromatic proton), $3.86\left(\mathrm{~s}, 2 \mathrm{H}\right.$, aliphatic, $\left.\mathrm{CH}_{2}\right), 3.72$ $\left(\mathrm{t}, 2 \mathrm{H}, J=6.0 \mathrm{~Hz}\right.$, aliphatic $\left.\mathrm{CH}_{2}\right), 3.63\left(\mathrm{~s}, 3 \mathrm{H}\right.$, aliphatic, $\left.\mathrm{OCH}_{3}\right), 3.34\left(\mathrm{~s}, 3 \mathrm{H}\right.$, aliphatic, $\left.\mathrm{OCH}_{3}\right), 1.15(\mathrm{t}, 2 \mathrm{H}, J=7.2$ $\mathrm{Hz}$, aliphatic $\left.\mathrm{CH}_{2}\right) ;{ }^{13} \mathrm{C} \mathrm{NMR}(100 \mathrm{MHz}$, DMSO-d $) \delta 158.7,153.2,151.4,146.7,139.4,133.2,130.9,129.4,128.4$, $127.4,124.9,114.1,112.0,56.1,55.9,31.4,29.4,14.1$.

\section{2-(4-Methoxybenzyl)-5-(4-methoxyphenethyl)-1,3,4-oxadiazole (4f)}

Yellowish solid; yield: $74 \%$; $\mathrm{R}_{f}: 0.61$ ( $n$-hexane : ethyl acetate, 8:2); FT-IR (v / $\left.\mathrm{cm}^{-1}\right): 3033\left(\mathrm{sp}^{2} \mathrm{CH}\right), 2951\left(\mathrm{sp}^{3} \mathrm{CH}\right)$, $1584(\mathrm{C}=\mathrm{N}), 1563,1510,1489\left(\mathrm{C}=\mathrm{C}\right.$ of phenyl ring); ${ }^{1} \mathrm{H}$ NMR (400 M Hz, DMSO-d $) \delta 7.36-7.23$ (m, $2 \mathrm{H}$, aromatic proton), 7.14-7.10 (m, 2H, aromatic proton), 7.09-7.05 (m, 4H, aromatic proton), $3.87\left(\mathrm{~s}, 2 \mathrm{H}\right.$, aliphatic $\left.\mathrm{CH}_{2}\right), 3.72(\mathrm{t}$, $2 \mathrm{H}, J=6.8 \mathrm{~Hz}$, aliphatic $\left.\mathrm{CH}_{2}\right), 3.63\left(\mathrm{~s}, 3 \mathrm{H}\right.$, aliphatic, $\left.\mathrm{OCH}_{3}\right), 3.13\left(\mathrm{~s}, 3 \mathrm{H}\right.$, aliphatic, $\left.\mathrm{OCH}_{3}\right), 1.09(\mathrm{t}, 2 \mathrm{H}, J=6.4 \mathrm{~Hz}$, aliphatic $\left.\mathrm{CH}_{2}\right) ;{ }^{13} \mathrm{C}$ NMR (100 MHz, DMSO- $\left.d_{6}\right) \delta 159.4,154.8,145.3,139.3,133.0,131.6,129.6,128.3,124.8$, $122.5,115.6,55.4,25.9,21.1$.

\section{2-(2-Fluorobenzyl)-5-(2-methoxyphenethyl)-1,3,4-oxadiazole (4g)}


Off white solid; yield: $74 \%$; $\mathrm{R}_{f}: 0.60$ ( $n$-hexane : ethyl acetate, 8:2); FT-IR $\left(\mathrm{v} / \mathrm{cm}^{-1}\right): 3037\left(\mathrm{sp}^{2} \mathrm{CH}\right), 2945\left(\mathrm{sp}^{3} \mathrm{CH}\right)$, $1584(\mathrm{C}=\mathrm{N}), 1571,1522,1501\left(\mathrm{C}=\mathrm{C}\right.$ of phenyl ring); ${ }^{1} \mathrm{H}$ NMR $\left(400 \mathrm{M} \mathrm{Hz}, \mathrm{DMSO}-d_{6}\right) \delta 7.50-7.44(\mathrm{~m}, 1 \mathrm{H}$, aromatic proton), 7.31-7.18 $(\mathrm{m}, 2 \mathrm{H}$, aromatic proton), 7.12-7.10 (m, 3H, aromatic proton), 6.90-6.75 $(\mathrm{m}, 2 \mathrm{H}$, aromatic proton), $3.78\left(\mathrm{~s}, 2 \mathrm{H}\right.$, aliphatic $\left.\mathrm{CH}_{2}\right), 3.72\left(\mathrm{t}, 2 \mathrm{H}\right.$, aliphatic, $\left.J=6.4 \mathrm{~Hz}, \mathrm{CH}_{2}\right), 3.68\left(\mathrm{~s}, 3 \mathrm{H}\right.$, aliphatic, $\left.\mathrm{OCH}_{3}\right), 1.25(\mathrm{t}$, $\left.2 \mathrm{H}, J=7.2 \mathrm{~Hz}, \mathrm{CH}_{2}\right) ;{ }^{13} \mathrm{C}$ NMR $\left(100 \mathrm{MHz}, \mathrm{DMSO}-d_{6}\right) \delta 158.5,154.9,146.7,139.2,133.2,130.1,129.6,128.4$, $127.4,124.9,114.1,55.4,31.6,29.2,14.9$.

\section{2-(2-Fluorophenethyl)-5-(2-methoxyphenethyl)-1,3,4-oxadiazole (4h)}

Off white solid; yield: $65 \%$; $\mathrm{R}_{f}: 0.54$ ( $n$-hexane : ethyl acetate, 8:2); FT-IR $\left(v / \mathrm{cm}^{-1}\right): 3041\left(\mathrm{sp}^{2} \mathrm{CH}\right), 2942\left(\mathrm{sp}^{3} \mathrm{CH}\right)$, $1584(\mathrm{C}=\mathrm{N}), 1548,1511,1489\left(\mathrm{C}=\mathrm{C}\right.$ of phenyl ring); ${ }^{1} \mathrm{H}$ NMR $\left(400 \mathrm{M} \mathrm{Hz}\right.$, DMSO- $\left.d_{6}\right) \delta 7.58-7.41(\mathrm{~m}, 1 \mathrm{H}$, aromatic proton), 7.32-7.23 $(\mathrm{m}, 2 \mathrm{H}$, aromatic proton), 7.19-7.11 (m, $2 \mathrm{H}$, aromatic proton), 6.90-6.74 $(\mathrm{m}, 3 \mathrm{H}$, aromatic proton), 3.78 (s, $2 \mathrm{H}$, aliphatic, $\left.\mathrm{CH}_{2}\right), 3.72\left(\mathrm{t}, 2 \mathrm{H}, J=6.4 \mathrm{~Hz}\right.$, aliphatic, $\left.\mathrm{CH}_{2}\right), 3.65\left(\mathrm{~s}, 3 \mathrm{H}\right.$, aliphatic, $\left.\mathrm{OCH}_{3}\right), 1.25(\mathrm{t}$, $2 \mathrm{H}, J=8.0 \mathrm{~Hz}$, aliphatic, $\left.\mathrm{CH}_{2}\right) ;{ }^{13} \mathrm{C}$ NMR $\left(100 \mathrm{MHz}\right.$, DMSO- $\left.d_{6}\right) \delta 158.4,155.1,149.3,147.0,139.2,133.2,130.1$, $129.6,128.4,127.4,124.9,114.1,112.0,55.4,31.6,29.2,14.9$.

\section{2,5-Bis(2-methoxyphenethyl)-1,3,4-oxadiazole (4i)}

Off white solid; yield: $63 \%$; $\mathrm{R}_{f}$ : 0.56 ( $n$-hexane : ethyl acetate, 8:2); FT-IR $\left(\mathrm{v} / \mathrm{cm}^{-1}\right): 3038\left(\mathrm{sp}^{2} \mathrm{CH}\right), 2937\left(\mathrm{sp}^{3} \mathrm{CH}\right)$, $1587(\mathrm{C}=\mathrm{N}), 1554,1522,1499\left(\mathrm{C}=\mathrm{C}\right.$ of phenyl ring); ${ }^{1} \mathrm{H}$ NMR $\left(400 \mathrm{M} \mathrm{Hz}\right.$, DMSO- $\left.d_{6}\right) \delta$ 7.56-7.39 (aromatic, 4H, m), 7.25-6.94 (aromatic, 4H, m), $3.56\left(\mathrm{~s}, 6 \mathrm{H}, \mathrm{OCH}_{3}\right), 2.90$ (t, $4 \mathrm{H}, J=6.0 \mathrm{~Hz}, \mathrm{CH}_{2}$ ), 2.88 (t, 4H, $J=6.0 \mathrm{~Hz}, \mathrm{CH}_{2}$ );

${ }^{13} \mathrm{C}$ NMR $\left(100 \mathrm{MHz}\right.$, DMSO- $\left.d_{6}\right) \delta 166.5,161.9,159.4,159.0,137.9,135.1,133.4,127.5,120.1,119.4,116.5,56.0$, $35.4,33.7$.

\section{2-(2-Methoxyphenethyl)-5-phenyl-1,3,4-oxadiazole (4j)}

Brown solid; yield: $76 \%$; $\mathrm{R}_{f}$ : 0.61 ( $n$-hexane : ethyl acetate, 8:2); FT-IR $\left(v / \mathrm{cm}^{-1}\right): 3051\left(\mathrm{sp}^{2} \mathrm{CH}\right), 2939\left(\mathrm{sp}^{3} \mathrm{CH}\right)$, $1585(\mathrm{C}=\mathrm{N}), 1561,1511,1499\left(\mathrm{C}=\mathrm{C}\right.$ of phenyl ring); ${ }^{1} \mathrm{H}$ NMR $\left(400 \mathrm{M} \mathrm{Hz}\right.$, DMSO- $\left.d_{6}\right) \delta 7.36-7.35(\mathrm{~m}, 1 \mathrm{H}$, aromatic proton), 7.29-7.23 $(\mathrm{m}, 2 \mathrm{H}$, aromatic proton $)$, 7.14-7.12 $(\mathrm{m}, 1 \mathrm{H}$, aromatic proton), 7.10-7.05 $(\mathrm{m}, 4 \mathrm{H}$, aromatic proton), 3.72 (t, $2 \mathrm{H}, J=6.4 \mathrm{~Hz}$, aliphatic, $\mathrm{CH}_{2}$ ), 3.68 (s, $3 \mathrm{H}$, aliphatic, $\left.\mathrm{OCH}_{3}\right), 1.25$ (t, $2 \mathrm{H}, J=7.2 \mathrm{~Hz}$, aliphatic, $\left.\mathrm{CH}_{2}\right) ;{ }^{13} \mathrm{C}$ NMR $\left(100 \mathrm{MHz}\right.$, DMSO- $\left.d_{6}\right) \delta 158.4,154.8,145.3,139.3,133.0,131.6,131.5,129.6,129.5,129.4,128.3$, $124.8,124.7,124.6,122.5,122.3,55.4,25.8,21.6$.

\section{2-(2-Methoxybenzyl)-5-(2-methoxyphenethyl)-1,3,4-oxadiazole (4k)}

Brown solid; yield: $69 \%$; $\mathrm{R}_{f}: 0.60$ ( $n$-hexane : ethyl acetate, 8:2); FT-IR $\left(v / \mathrm{cm}^{-1}\right): 3041\left(\mathrm{sp}^{2} \mathrm{CH}\right), 2948\left(\mathrm{sp}^{3} \mathrm{CH}\right)$, $1589(\mathrm{C}=\mathrm{N}), 1560,1510,1484\left(\mathrm{C}=\mathrm{C}\right.$ of phenyl ring); ${ }^{1} \mathrm{H}$ NMR $\left(400 \mathrm{M} \mathrm{Hz}, \mathrm{DMSO}-d_{6}\right) \delta 7.29-7.23(\mathrm{~m}, 2 \mathrm{H}$, aromatic proton), 7.14-7.11 (m, $2 \mathrm{H}$, aromatic proton), 7.10-7.00 (m, $2 \mathrm{H}$, aromatic proton), 6.99-6.80 $(\mathrm{m}, 2 \mathrm{H}$, aromatic proton), $3.78\left(\mathrm{~s}, 2 \mathrm{H}\right.$, aliphatic, $\left.\mathrm{CH}_{2}\right), 3.73\left(\mathrm{t}, 2 \mathrm{H}, J=6.0 \mathrm{~Hz}\right.$, aliphatic, $\left.\mathrm{CH}_{2}\right), 3.72\left(\mathrm{~s}, 3 \mathrm{H}\right.$, aliphatic, $\left.\mathrm{OCH}_{3}\right), 3.71(\mathrm{~s}$, $3 \mathrm{H}$, aliphatic, $\left.\mathrm{OCH}_{3}\right), 1.24\left(\mathrm{t}, 2 \mathrm{H}, J=7.2 \mathrm{~Hz}\right.$, aliphatic, $\left.\mathrm{CH}_{2}\right) ;{ }^{13} \mathrm{C} \mathrm{NMR}\left(100 \mathrm{MHz}, \mathrm{DMSO}-d_{6}\right) \delta 158.7,154.8$, $151.4,146.7,133.3,131.2,129.7,129.0,114.1,112.0,56.1,55.9,25.9,21.1$.

\section{Synthesis of substituted 1,2,4-triazole derivatives 6}

Potassium hydroxide $(0.125 \mathrm{~mol}$, 1eq) was dissolved in dry methanol $(50 \mathrm{~mL})$. To the solution, substituted acid hydrazides 3 ( $0.125 \mathrm{~mol}, 1$ eq) was added and cooled the solution in ice. To this, carbon disulfide $(0.125 \mathrm{~mol}$, leq) 
was added with constant stirring for 1-2 h. The solid product of potassium salt of hydrazinecarbodithioates $\mathbf{5}$ formed, was filtered, washed with chilled diethyl ether and dried. It was directly used for next step without further purification. The potassium salt of hydrazinecarbodithioates 5 was taken in deionized water $(50 \mathrm{~mL})$ and hydrazine hydrate $(0.250 \mathrm{~mol})$ was added, followed by reflux overnight. The reaction mixture turned to yellowish green with evolution of hydrogen sulfide and finally it became homogeneous. It was then poured in crushed ice and neutralized with hydrochloric acid to afford white precipitates of substituted triazole derivatives $\mathbf{6}$ which was filtered, washed with cold water and crystallized on methanol.

\section{Synthesis of Schiff base derivatives 7a-k}

The corresponding substituted triazole derivatives $6(0.125 \mathrm{~mol}$, 1eq) was dissolved in methanol $(20 \mathrm{~mL})$ and different substituted aldehydes $(0.125 \mathrm{~mol}, 1 \mathrm{eq})$ was separately dissolved in methanol $(20 \mathrm{~mL})$ and both solutions were mixed together prior to exposure with microwave for 10 min with constant monitoring the reaction progress by TLC after regular interval of two min. On complete consumption of starting materials, the extra solvent was evaporated on reduced pressure and resulting powder was crystallized on methanol. The purification of product was done by column chromatography with $n$-hexane: ethyl acetate solvent system and crystallized on methanol.

\section{(E)-3-(2-fluorophenyl)-4-[(thiophen-2-ylmethylene)amino]-1H-1,2,4-triazole-5(4H)-thione (7a)}

Light pink; yield: $83 \%$; Rf: 0.54 (chloroform : methanol, 9:1); ${ }^{1} \mathrm{H}$ NMR (400 MHz, DMSO- $\left.d_{6}\right) \delta 13.88$ (s, $\left.1 \mathrm{H}, \mathrm{NH}\right)$, $10.16(\mathrm{~s}, 1 \mathrm{H}$, imine proton), 7.96-7.95 $(\mathrm{m}, 1 \mathrm{H}$, aromatic proton), 7.79-7.77 $(\mathrm{m}, 1 \mathrm{H}$, aromatic proton), 7.38-7.29 $(\mathrm{m}$, $2 \mathrm{H}$, aromatic proton), 7.27-7.26 $\left(\mathrm{m}, 1 \mathrm{H}\right.$, aromatic proton), 7.25-7.13 $\left(\mathrm{m}, 1 \mathrm{H}\right.$, aromatic proton); ${ }^{13} \mathrm{C} \mathrm{NMR}(100 \mathrm{MHz}$, DMSO- $\left.d_{6}\right) \delta 162.1,159.6,157.7,149.5,136.8,136.2,133.4,131.9,129.7,128.9,124.9,122.3,115.8$.

\section{(E)-3-(2-bromophenyl)-4-[(thiophen-2-ylmethylene)amino]-1H-1,2,4-triazole-5(4H)-thione (7b)}

Light gray; yield: $84 \%$; Rf: 0.54 (chloroform : methanol, 9:1); ${ }^{1} \mathrm{H}$ NMR (400 MHz, DMSO- $\left.d_{6}\right) \delta 13.78$ (s, 1H, NH), $10.18(\mathrm{~s}, 1 \mathrm{H}$, imine proton), 7.95-7.72 $(\mathrm{m}, 1 \mathrm{H}$, aromatic proton), 7.57-7.49 $(\mathrm{m}, 1 \mathrm{H}$, aromatic proton), 7.47-7.27 (m, $2 \mathrm{H}$, aromatic proton), 7.27-7.20 (m, $2 \mathrm{H}$, aromatic proton); ${ }^{13} \mathrm{C}$ NMR (100 MHz, DMSO- $\left.d_{6}\right) \delta 162.7,162.0,157.4$, $151.4,150.2,136.9,136.1,135.3,134.9,133.3,131.8,129.0,120.5$.

\section{(E)-3-(2-methoxyphenyl)-4-[(thiophen-2-ylmethylene)amino]-1H-1,2,4-triazole-5(4H)-thione (7c)}

Light pink; yield: $86 \%$; Rf: 0.53 (chloroform : methanol, 9:1); ${ }^{1} \mathrm{H}$ NMR (400 MHz, DMSO- $\left.d_{6}\right) \delta 13.71$ (s, $1 \mathrm{H}, \mathrm{NH}$ ), $10.16(\mathrm{~s}, 1 \mathrm{H}$, imine proton), 7.97-7.80 $(\mathrm{m}, 1 \mathrm{H}$, aromatic proton), 7.79-7.64 $(\mathrm{m}, 1 \mathrm{H}$, aromatic proton), 7.28-7.18 $(\mathrm{m}$, $3 \mathrm{H}$, aromatic proton), 6.96-6.84 (m, $2 \mathrm{H}$, aromatic proton), $3.73\left(\mathrm{~s}, 3 \mathrm{H}, \mathrm{OCH}_{3}\right) ;{ }^{13} \mathrm{C} \mathrm{NMR}\left(100 \mathrm{MHz}, \mathrm{DMSO}-d_{6}\right) \delta$ $161.9,158.6,157.3,151.0,136.9,136.1,133.3,130.5,129.0,128.7,127.2,114.3,55.5$.

\section{(E)-4-[\{(1H-pyrrol-2-yl)methylene $\}$ amino]-3-(2-fluorophenyl)-1 H-1,2,4-triazole-5(4H)-thione (7d)}

Off white; yield: $86 \%$; $\mathrm{R}_{f}: 0.53$ (chloroform : methanol, 9:1); ${ }^{1} \mathrm{H}$ NMR (400 MHz, DMSO- $\left.d_{6}\right) \delta 13.78$ (s, $1 \mathrm{H}, \mathrm{NH}$ ), $9.57(\mathrm{~s}, 1 \mathrm{H}$, imine proton), 7.57-7.50 (m, $2 \mathrm{H}$, aromatic proton), 7.49-7.45 (m, 3H, aromatic proton), 7.29-7.17 (m, $1 \mathrm{H}$, aromatic proton), 6.82-6.80 (m, $1 \mathrm{H}$, aromatic proton), 6.24-6.22 $\left(\mathrm{m}, 1 \mathrm{H}\right.$, aromatic proton), $5.55(\mathrm{~s}, 1 \mathrm{H}, \mathrm{NH}) ;{ }^{13} \mathrm{C}$ NMR $\left(100 \mathrm{MHz}, \mathrm{DMSO}-d_{6}\right) \delta 161.8,156.4,150.0,135.1,132.0,131.8,131.5,125.5,120.4,120.2,109.9$.

\section{(E)-4-[\{(1H-pyrrol-2-yl)methylene\}amino]-3-(2-methoxyphenyl)-1H-1,2,4-triazole-5(4H)-thione (7e)}

Ivory; yield: $83 \%$; $\mathrm{R}_{f}: 0.52$ (chloroform : methanol, 9:1); ${ }^{1} \mathrm{H}$ NMR (400 MHz, DMSO- $\left.d_{6}\right) \delta 13.76(\mathrm{~s}, 1 \mathrm{H}, \mathrm{NH}), 9.57$ (s, $1 \mathrm{H}$, imine proton), 7.43-7.30 (m, $2 \mathrm{H}$, aromatic proton), 7.27-7.11 (m, $3 \mathrm{H}$, aromatic proton), 6.86-3.81 (m, $1 \mathrm{H}$, 
aromatic proton), 6.29-6.22 (m, 1H, aromatic proton), $5.59(\mathrm{~s}, 1 \mathrm{H}, \mathrm{NH}), 3.81\left(\mathrm{~s}, 3 \mathrm{H}, \mathrm{OCH}_{3}\right) ;{ }^{13} \mathrm{C} \mathrm{NMR}(100 \mathrm{MHz}$, DMSO- $\left.d_{6}\right) \delta 162.0,159.6,156.4,149.4,132.0,129.7,125.5,124.9,122.5,120.2,115.8,109.9,55.5$.

\section{(E)-3-(3-fluorophenyl)-4-[(2-phenylpropylidene)amino]-1H-1,2,4-triazole-5(4H)-thione (7f)}

Brown; yield: $81 \%$; $\mathrm{R}_{f}: 0.56$ (chloroform : methanol, 9:1); ${ }^{1} \mathrm{H}$ NMR (400 MHz, DMSO- $\left.d_{6}\right) \delta 13.56$ (s, $1 \mathrm{H}, \mathrm{NH}$ ), $10.14(\mathrm{~s}, 1 \mathrm{H}$, imine proton), 7.86-7.50 (m, 3H, aromatic proton), 7.46-7.11 (m, 5H, aromatic proton), 2.99-2.90 (m, $1 \mathrm{H}$, aliphatic proton), 1.94 (d, $3 \mathrm{H}, J=6.4$, aliphatic proton); ${ }^{13} \mathrm{C}$ NMR (100 MHz, DMSO- $\left.d_{6}\right) \delta 166.6,151.4,135.3$, $131.8,131.6,125.5,120.4,114.4,30.09,18.4$.

\section{(E)-3-(3-bromophenyl)-4-[(2-phenylpropylidene)amino]-1H-1,2,4-triazole-5(4H)-thione (7g)}

Antique white; yield: $82 \%$; $\mathrm{R}_{f}$ : 0.56 (chloroform : methanol, 9:1); ${ }^{1} \mathrm{H}$ NMR (400 MHz, DMSO- $\left.d_{6}\right) \delta 13.66(\mathrm{~s}, 1 \mathrm{H}$, $\mathrm{NH}), 10.18(\mathrm{~s}, 1 \mathrm{H}$, imine proton), 7.96-7.95 $(\mathrm{m}, 1 \mathrm{H}$, aromatic proton), 7.78-7.72 (m, 1H, aromatic proton), 7.57-7.44 $(\mathrm{m}, 3 \mathrm{H}$, aromatic proton), 7.32-7.20 $(\mathrm{m}, 4 \mathrm{H}$, aromatic proton), 2.85-2.72 $(\mathrm{m}, 1 \mathrm{H}$, aliphatic proton), $1.24(\mathrm{~d}, 3 \mathrm{H}$, aliphatic proton); ${ }^{13} \mathrm{C}$ NMR $\left(100 \mathrm{MHz}, \mathrm{DMSO}-d_{6}\right) \delta 162.0,157.4,151.4,150.2,136.9,136.1,135.3,134.9,133.3$, $131.7,129.0,120.5,30.5,19.4$.

\section{(E)-3-(3-methoxyphenyl)-4-[(2-phenylethylidene)amino]-1H-1,2,4-triazole-5(4H)-thione (7h)}

Violet; yield: $81 \%$; $\mathrm{R}_{f}$ : 0.52 (chloroform : methanol, 9:1); ${ }^{1} \mathrm{H}$ NMR (400 MHz, DMSO- $\left.d_{6}\right) \delta 13.73$ (s, $1 \mathrm{H}, \mathrm{NH}$ ), $10.16(\mathrm{~s}, 1 \mathrm{H}$, imine proton), 7.97-7.95 $(\mathrm{m}, 1 \mathrm{H}$, aromatic proton), 7.81-7.64 $(\mathrm{m}, 1 \mathrm{H}$, aromatic proton), 7.28-7.18 $(\mathrm{m}$, $5 \mathrm{H}$, aromatic proton), 6.90-6.84 (m, $2 \mathrm{H}$, aromatic proton), $4.02\left(\mathrm{~s}, 2 \mathrm{H}\right.$, aliphatic), $3.96\left(\mathrm{~s}, 3 \mathrm{H}, \mathrm{OCH}_{3}\right) ;{ }^{13} \mathrm{C}$ NMR $\left(100 \mathrm{MHz}, \mathrm{DMSO}-d_{6}\right) \delta 161.9,158.6,157.3,152.1,138.9,136.9,136.1,134.2,133.3,131.4,130.5,129.0,127.7$, $114.3,55.5,30.3$.

\section{(Z)-4-[(2-fluorobenzylidene)amino]-3-(4-fluorobenzyl)-1H-1,2,4-triazole-5(4H)-thione (7i)}

Antique white; yield: $83 \%$; $\mathrm{R}_{f}$ : 0.54 (chloroform : methanol, 9:1); ${ }^{1} \mathrm{H}$ NMR (400 MHz, DMSO- $\left.d_{6}\right) \delta 13.89(\mathrm{~s}, 1 \mathrm{H}$, $\mathrm{NH}), 10.04(\mathrm{~s}, 1 \mathrm{H}$, imine proton), 7.98-7.86 (m, 2H, aromatic proton), 7.39-7.32 (m, 2H, aromatic proton), 7.31-7.27 (m, $2 \mathrm{H}$, aromatic proton), 7.22-7.11 (m, $2 \mathrm{H}$, aromatic proton), $4.10\left(\mathrm{~s}, 2 \mathrm{H}\right.$, aliphatic $\left.\mathrm{CH}_{2}\right) ;{ }^{13} \mathrm{C} \mathrm{NMR}(100 \mathrm{MHz}$, DMSO- $\left.d_{6}\right) \delta 163.3,163.0,162.4,162.0,159.6,149.8,131.9,131.6,129.8,129.2,124.9,116.9,115.8,30.1$.

\section{(Z)-4-[(2-fluorobenzylidene)amino]-3-(4-methoxyphenyl)-1H-1,2,4-triazole-5(4H)-thione (7j)}

Thistle; yield: $81 \%$; $\mathrm{R}_{f}: 0.51$ (chloroform : methanol, 9:1); ${ }^{1} \mathrm{H}$ NMR (400 MHz, DMSO- $\left.d_{6}\right) \delta 13.53$ (s, $\left.1 \mathrm{H}, \mathrm{NH}\right)$, $10.03(\mathrm{~s}, 1 \mathrm{H}$, imine proton), 7.99-7.91 (m, $2 \mathrm{H}$, aromatic proton), 7.51-7.34 (m, $2 \mathrm{H}$, aromatic proton), 7.22-7.13 (m, $2 \mathrm{H}$, aromatic proton), 6.89-6.80 (m, $2 \mathrm{H}$, aromatic proton), $3.71\left(\mathrm{~s}, 3 \mathrm{H}, \mathrm{OCH}_{3}\right) ;{ }^{13} \mathrm{C} \mathrm{NMR}\left(100 \mathrm{MHz}, \mathrm{DMSO}-d_{6}\right) \delta$ $162.2,160.8,158.6,152.1,151.1,131.6,131.1,130.4,129.3,127.7,127.3,116.9,114.4,55.5$.

\section{(E)-3-(4-methoxybenzyl)-4-[(thiophen-2-ylmethylene)amino]-1H-1,2,4-triazole-5(4H)-thione (7k)}

Yellow; yield: $89 \%$; $\mathrm{R}_{f}$ : 0.52 (chloroform : methanol, 9:1); ${ }^{1} \mathrm{H}$ NMR (400 MHz, DMSO- $\left.d_{6}\right) \delta 13.88$ (s, $\left.1 \mathrm{H}, \mathrm{NH}\right)$, $10.16(\mathrm{~s}, 1 \mathrm{H}$, imine proton), 7.96-7.94 $(\mathrm{m}, 1 \mathrm{H}$, aromatic proton), 7.79-7.77 $(\mathrm{m}, 1 \mathrm{H}$, aromatic proton), 7.38-7.29 $(\mathrm{m}$, $2 \mathrm{H}$, aromatic proton), 7.27-7.26 (m, $1 \mathrm{H}$, aromatic proton), 7.26-7.13 (m, $2 \mathrm{H}$, aromatic proton), $4.18\left(\mathrm{~s}, 3 \mathrm{H}, \mathrm{OCH}_{3}\right)$, $3.40\left(\mathrm{~s}, 2 \mathrm{H}\right.$, aliphatic, $\left.\mathrm{CH}_{2}\right) ;{ }^{13} \mathrm{C}$ NMR $\left(100 \mathrm{MHz}, \mathrm{DMSO}-d_{6}\right) \delta 162.1,159.6,157.7,149.5,136.8,136.2,133.4$, $131.9,129.7,128.9,124.9,122.3,115.8,55.5$.

\section{Single crystal X-ray diffraction analysis}

The crystallographic data obtained for compound $\mathbf{7 k}$ are shown in Table $\mathbf{1}$ 


\section{$\underline{\underline{\text { Table } 1}}$}

\section{Structure solution and refinements}

Data collection: APEX II (Bruker, 2005); cell refinement: SAINT (Bruker, 2005); data reduction: SAINT (Bruker, 2005); program(s) used to solve structure: SHELXS97 (Sheldrick, 2008); program(s) used to refine structure: SHELXL97 (Sheldrick, 2008); molecular graphics: SHELXTL (Sheldrick, 2008); computing molecular graphics and material was performed by Ortep-3 for Windows (Farrugia, 2012)and WinGX publication routines (Farrugia, 2012). The CIF file for crystal is given in supporting information. The crystallographic data have been deposited with the Cambridge Crystallographic Data Centre as supplementary publication No. CCDC-1033154.

\section{Pharmacology}

\section{Protocol for in vitro bioassay}

\section{a-Glucosidase inhibition assay protocol}

The enzyme inhibition activity for $\alpha$-glucosidase was determined by the reported method with slight modification [51]. The assay solution consisted of $50 \mu \mathrm{L}$ of $(0.1 \mathrm{M})$ sodium phosphate buffer $\mathrm{pH} 7.0,25 \mu \mathrm{L}$ of $(0.5 \mathrm{mM})$ substrate (p-nitrophenyl- $\alpha$-D-glucopyranoside), $20 \mu \mathrm{L}$ of increasing concentration of test compounds and $25 \mu \mathrm{L}$ of enzyme solution. This reaction mixture was then incubated for $30 \mathrm{~min}$ at $37^{\circ} \mathrm{C}$. Then, the reaction was stopped by the addition of $100 \mu \mathrm{L}$ of $(0.2 \mathrm{M})$ sodium carbonate solution followed by the measurement of absorbance at $405 \mathrm{~nm}$. For non-enzymatic reaction, the assays were carried out with a blank containing all components except enzyme. The assay measurements were carried out by using a micro plate reader (OPTI ${ }_{\text {Max }}$, Tunable). The reaction rates of the tested compounds were compared with the reference drug and the percent inhibition was calculated by using the formula $100-\left(\mathrm{Abs}_{\text {testwell }} / \mathrm{Abs}_{\text {control }}\right) \times 100$ [52]. Acarbose was used as a reference inhibitor. Each concentration was analyzed in three independent experiments run in triplicate. The $\mathrm{IC}_{50}$ values determined by the Data analysis and graphing software, Origin 8.6, 64-bit.

\section{Kinetic analysis for the $\alpha$-glucosidase inhibition assay}

A series of experiments were performed to determine the inhibition kinetics by following the reported method [5153]. Briefly, for each of three different concentrations of inhibitor compounds $4 \mathbf{b}(0 \mathrm{mM}, 1.6 \mathrm{mM}$ and $3.2 \mathrm{mM})$ and $4 \mathbf{c}(0 \mathrm{mM}, 0.096 \mathrm{mM}$ and $1.58 \mathrm{mM})$, respectively, the substrate $p$-nitrophenol- $\alpha$-D-glucopyranoside ( $p$-NPG) concentration was varied in the order of $1.25 \mathrm{mM}, 2.5 \mathrm{mM}$ and $5 \mathrm{mM}$, respectively. Pre-incubation and measurement time was the same as discussed in $\alpha$-Glucosidase inhibition assay protocol. Maximal initial velocity was determined from initial linear portion of absorbance up to five minutes after addition of $\alpha$-Glucosidase at a $15 \mathrm{~s}$ interval. The inhibition type on the enzyme was assayed by Lineweaver-Burk plots of inverse of velocities $(1 / V)$ versus inverse of substrate concentration $1 /[\mathrm{S}] \mathrm{mM}^{-1}$, and the inhibition constant $K_{i}$ was determined by secondary plot of $\mathrm{Km}$ versus the concentration of inhibitor $\mathbf{4 b}$. In case of compound $\mathbf{4 c}$ the enzyme inhibitor (EI) dissociation constant $K_{i}$ was determined by secondary plot of slope versus $4 \mathbf{c}$ concentrations while enzyme substrate inhibitor (ESI) dissociation constant $K_{i^{\prime}}$ was determined by intercept versus $4 \mathbf{c}$ concentrations.

\section{Molecular Docking studies}

\section{Preparation of receptor}

Molecular Operating Environment (MOE 2014) by Chemical Computing Group (CCG) was used for current studies [54]. The protein preparation step involved 3D protonation, energy minimization and active site identification. The 
crystal structure of Jack Bean Urease was obtained from protein data bank (PDB code:3AL4) [55]. The cocrystallized bound compounds and water molecules were stripped off from the crystal structure. Protein was energy minimized and 3-D protonated by using the structure preparation module of MOE. Since, the protein was devoid of co-crystallized ligand therefore active site was identified by using site finder module of the MOE. The chain with the both nickel ions was selected to find the active site. The pocket was found to be deep cleft lined with the two nickel ions and both hydrophobic and hydrophilic amino acid residues.

\section{Preparation of Ligands}

The ligand files for molecular docking studies were prepared in MOE-2014 and were followed by energy optimization at standard MMFF94 force field level, with a $0.0001 \mathrm{kcal} / \mathrm{mol}$ energy gradient convergence criterion $[55,56]$. The optimized geometries were saved in molecular data base $(\mathrm{mdb})$ file for further studies.

\section{Molecular Docking studies against $\alpha$-glucosidase}

The optimized ligands were docked with the modeled yeast $\alpha$-glucosidase protein, which was carried out in another studies [57], using the MOE-Dock suite. The Placement, Rescoring 1 and Rescoring 2 were set as Triangle Matcher, London $\mathrm{dG}$ and affinity $\mathrm{dG}$, respectively. Algorithm with two rescoring functions London $\mathrm{dG}$ and GBVI/WSA dG were utilized to generate 30 poses of each compound. As a result of docking run mdb output files were generated enclosing all docking results with scoring and multiple conformations of ligands. The resulting conformations and their energies were recorded to a molecular database file. The top ranked conformation (best scored pose) for each compound was chosen for further studies of interaction evolution and validation. The $2 \mathrm{D}$ ligand-protein interactions were visualized using the MOE ligand interactions program. Since, the 3D structure of yeast $\alpha$-glucosidase has not yet been determined by any experimental methods, we took the 3D coordinates of the modeled yeast $\alpha$-glucosidase which was used as our target protein [57].

\section{Urease inhibition assay protocol}

The urease activity was determined by measuring amount of ammonia produced by indophenols method [58, 59]. Briefly, the assay mixture, containing $10 \mu \mathrm{L}$ of enzyme $(5 \mathrm{U} / \mathrm{mL})$ and $10 \mu \mathrm{L}$ of test samples in $40 \mu \mathrm{L}$ buffer $(100$ $\mathrm{mM}$ urea, $0.01 \mathrm{M} \mathrm{K}_{2} \mathrm{HPO}_{4}, 1 \mathrm{mM}$ EDTA and $0.01 \mathrm{M} \mathrm{LiCl}_{2}, \mathrm{pH} 8.2$ ), were incubated for $30 \mathrm{~min}$ at $37{ }^{\circ} \mathrm{C}$ in 96 -well plate. The $40 \mu \mathrm{L}$ each of phenol reagents $(1 \%$, w/v phenol and $0.005 \%$, w/v sodium nitroprusside) and $40 \mu \mathrm{L}$ of alkali reagent $(0.5 \%, \mathrm{w} / \mathrm{v} \mathrm{NaOH}$ and $0.1 \%$ active chloride $\mathrm{NaOCl})$ were added to each well. The absorbance at 625 $\mathrm{nm}$ was measured after $30 \mathrm{~min}$, using a microplate reader (OPTI ${ }_{\text {Max }}$, Tunable). All reactions were performed in triplicate and thiourea was used as the standard inhibitor of urease.

\section{Kinetic analysis for the Urease inhibition assay}

Lineweaver-Burk plots of $1 /$ absorbance versus $1 /$ Urea were used to determine the type of inhibition. Urease inhibition was measured by varying the concentration of urea in the presence of different concentrations $(0,13.7$, 27.5 and $55 \mu \mathrm{M})$ of the tested compound (7b). The EI dissociation constant $(\mathrm{Ki})$ was determined by secondary replot of slope versus inhibitors concentrations while ESI dissociation constant $\left(\mathrm{Ki}^{\prime}\right)$ was determined as the intersection on the $\mathrm{X}$-axis of the secondary replot of $1 / V$ (y-intercept of Lineweaver-Burk plot) versus inhibitor concentrations. Briefly the urea concentration was changed from 3.12 to $100 \mathrm{mM}$ for urease kinetics studies and remaining procedure was same as describes in urease inhibition assay protocol. Urease activity was determined by measuring ammonia production using the indophenol method as reported previously [60]. The results (change in absorbance per min) were processed by using SoftMaxPro software. 


\section{Molecular Docking studies against Urease}

The optimized ligands were docked with the Jack Bean Urease (PDB code:3AL4) protein using the MOE-Dock program [54]. A total of 30 independent docking runs were performed using MOE docking simulation program. All the docked conformations were analyzed and the best scored pose for each compound was opted for further studies of interaction evaluation. The 2D ligand-protein interactions were visualized using the MOE ligand interactions program. Default MOE docking parameters i.e., Triangle Matcher, Algorithm with two rescoring functions London $\mathrm{dG}$ and GBVI/WSA dG were utilized to generate 30 poses of each compound. As a result of docking run mdb output files were generated enclosing all docking results with scoring and multiple conformations of ligands.

\section{Results and discussion}

\section{Synthesis of target compounds $4 a-k$ and $7 a-k$}

The conversion of substituted carboxylic acids $\mathbf{1}$ to the substituted acid chlorides $\mathbf{2}$ were indicated in the FT-IR spectral data by the disappearance of broad signal in the range of $3400-2500 \mathrm{~cm}^{-1}$ due to acid hydroxyl group. The formation of substituted acid hydrazides 3 were indicated in the IR spectra by the appearance of new signal at 3346 , 3296 and 3156 due to primary and secondary amino group of acid hydrazides. Meanwhile there was slight shift in the carbonyl stretching vibration from 1733-1634 $\mathrm{cm}^{-1}$ indicating the successful conversion of substituted acid chlorides 2 into substituted aromatic acid hydrazides 3 . In the ${ }^{1} \mathrm{H}$ NMR spectrum, the appearance of broad singlet due to primary and secondary amino group at $9.23 \mathrm{ppm}$ as well as $4.25 \mathrm{ppm}$, respectively, further confirms the successful synthesis of $\mathbf{3}$. The coupling of substituted aromatic acid hydrazides $\mathbf{3}$ with several substituted carboxylic acids were carried out by refluxing with phosphorus oxychloride at $107{ }^{\circ} \mathrm{C}$ which afford corresponding 2,5 disubstituted 1,3,4-oxadiazole derivatives 4a-k. The disappearance of signal at 3346, 3296 and 3156 due to primary and secondary amino group of acid hydrazides gives indication for the formation of substituted oxadiazole derivatives. The further confirmation was done by NMR spectral analysis.

Meanwhile, the formation of substituted triazole derivatives 6 were characterized by the FT-IR, ${ }^{1} \mathrm{H}$ NMR and ${ }^{13} \mathrm{C}$ NMR spectral data. In the FT-IR spectra, a relatively broad peak in the range of $3280,3169 \mathrm{~cm}^{-1}$ with shoulder for $\mathrm{NH}_{2}$ stretching vibration and a new signal at $1321 \mathrm{~cm}^{-1}$ for $\mathrm{C}=\mathrm{S}$ stretching vibration indicate the transformation of $\mathbf{3}$ into 6. In the ${ }^{1} \mathrm{H}$ NMR, a characteristic highly downfield signal at $13.57 \mathrm{ppm}$ due to triazole ring secondary amino proton resolution confirms the formation of $\mathbf{6}$. The condensations of $\mathbf{6}$ with different substituted aldehydes were confirms by NMR $\left({ }^{1} \mathrm{H}\right.$ NMR \& ${ }^{13} \mathrm{C}$ NMR $)$ spectral analysis. The slight down field shift in the NH signal from 13.57 ppm to $13.88 \mathrm{ppm}$ and complete disappearance of $\mathrm{NH}_{2}$ signal at $5.60 \mathrm{ppm}$ confirms the Schiff base formation. In the meantime, the appearance of down field singlet in the range of 10.03-10.18 ppm due to imine proton and emergence of additional signals in both carbon and proton NMR spectra further confirmed the successful conversion of 6 into 7.

\section{Thione-thiol tautomerism in the compounds $7 \mathbf{a}-\mathbf{k}$}

The target compounds 7a-k have labile hydrogen atom in the 1,2,4-triazole nucleus and there is possibility for this hydrogen atom to stay whether on the ring nitrogen atom or it may stay on the sulfur atom connected to the 5membered ring structure. Due to this replaceable nature of hydrogen atom, theoretically, the two tautomeric conformational structures of the resulting molecules are possible as shown in the Scheme 2. The preliminary investigations about the predominant conformational structure of the synthesized analogues were done by recording the FT-IR spectra. There were clear indications about the thione tautomer of the compounds 7a-k in the FT-IR spectral analysis as there was no signal appearance in the range of $2500-2400 \mathrm{~cm}^{-1}$ due to terminal thiol strectching viabration. The absence of - SH signal in the FT-IR spectra support the thione conformatinal structure of the synthesized molecules. For better understanding about the predominant isomer of 1,2,4-triazole's Schiff bases, one of the compound $\mathbf{7 k}$ was characterized by the single crystal X-ray diffraction analysis and from the single crystal 
data of the molecule $7 \mathbf{k}$, it can be clearly found that molecule predominantly exist in thione tautomeric conformation as shown in Fig. 3.

\section{Scheme 2, Fig. 3}

The packing diagram of $\mathbf{7} \mathbf{k}$ showed the formation of molecular chains parallel to the short $\mathrm{x}$ axis via classical inversion-symmetric $\mathrm{H}$ bonding systems. The exclusive presence of the $\mathrm{NH}-\mathrm{C}=\mathrm{S}$ tautomer is confirmed by the relevant molecular dimensions and by the direct localization and free refinement of the NH hydrogen. In the crystal structure, intermolecular N-H---S hydrogen bonds (Fig. 4) link the molecule to infinite chain, which seems to be effective in the stabilization of the crystals. The bond length $[\AA]$ and bond angle $\left[{ }^{\circ}\right]$ for hydrogen bond of $7 \mathbf{k}$ are shown in Table 2.

\section{$\underline{\underline{\text { Fig. } 4} \text { and Table } 2}$}

\section{Molecular geometry}

The crystal suitable for X-ray diffraction analysis was obtained by the slow evaporation of methanolic solution of 7k at room temperature and the single crystal data was obtained by using Bruker SMART APEX II X-ray diffractometer equipped with Mo X-ray tube, graphite monochromator and CCD detector at 100(1) K. The H atom of the $\mathrm{NH}$ group was refined freely and methyl groups were refined as an idealized rigid groups allowed to rotate but not tip; other $\mathrm{H}$ atoms were included using a riding model. The final wR2 was 0.1038 and 0.1111 for all reflections with conventional R1 values of 0.0410 and 0.0488 . The experimental structural parameters including bond length and bond angles of the molecule are tabulated in the Table 3, $\mathbf{4}$ and in accordance, the atom numbering scheme are given in Fig. 3. Briefly, in the target compound 7k, the $\mathrm{N}(1)-\mathrm{C}(5)$ and $\mathrm{N}(1)-\mathrm{C}(2)$ bond length was $1.378(2)$ and 1.3811(19) $\AA$, respectively, which lies in between double and single bond suggesting the delocalization of electronic cloud inside the triazole ring. Meanwhile, the $\mathrm{C}(2)-\mathrm{S}(13)$ bond length was 1.6795(18) $\AA$ which represent the $\mathrm{C}=\mathrm{S}$ character as the bond length for C-SH has been reported as $1.80 \AA$ [61]. These facts give solid evidence about the involvement of molecule into thione-thiol tautomerism but the predominant conformation of compound $7 \mathbf{k}$ is the thione conformation as shown by the molecular structure of $7 \mathbf{k}$ (Fig. 3). The rest of bond length for triazole skeleton was $\mathrm{N}(4)-\mathrm{C}(5)$; $1.299(2), \mathrm{C}(2)-\mathrm{N}(3) ; 1.338(2), \mathrm{N}(3)-\mathrm{N}(4) ; 1.377(2)$ and $\mathrm{N}(3)-\mathrm{H}(3) ; 0.85(2) \AA$. Furthermore, the $\mathrm{N}(1)-\mathrm{N}(6)$ exhibited single bond character as the bond length values reside at 1.4037(18) while the bond length values for the $\mathrm{N}(6)-\mathrm{C}(7)$ was observed at 1.281(2) clearly showing the double bond character and this is the linking site via imine bond formation between triazole skeleton and the side coupled group. In the same manner, the bond length for the $\mathrm{C}(8)-\mathrm{S}(9)$ and $\mathrm{S}(9)-\mathrm{C}(10)$ was $1.7242(17)$ and 1.703(2), respectively, completely match with the reported thiophene $\mathrm{C}-\mathrm{S}$ bond length. While the bond length for the rest of thiophene skeleton $i$. e., $\mathrm{C}(8)-\mathrm{C}(12)$; 1.370(2), $\mathrm{C}(10)-\mathrm{C}(11) ; 1.345(3), \mathrm{C}(11)-\mathrm{C}(12) ; 1.415(3)$ exhibited slight deviation from the standard bond length for the single and double bonds which is due to the delocalization of the electronic cloud inside the thiophene moiety. Moreover, the bond length for the rest of molecules was within the normal range as shown in the Table 3 .

\section{$\underline{\underline{\text { Table } 3}}$}

The bond angles in the molecule $7 \mathbf{k}$ were within the normal range. Briefly, the bond angles for methoxy substituent including $\mathrm{O}(21)-\mathrm{C}(22)-\mathrm{H}(22 \mathrm{~A}), \mathrm{O}(21)-\mathrm{C}(22)-\mathrm{H}(22 \mathrm{~B}), \mathrm{H}(22 \mathrm{~A})-\mathrm{C}(22)-\mathrm{H}(22 \mathrm{~B}), \mathrm{O}(21)-\mathrm{C}(22)-\mathrm{H}(22 \mathrm{C}), \mathrm{H}(22 \mathrm{~A})-\mathrm{C}(22)-$ $\mathrm{H}(22 \mathrm{C})$ and $\mathrm{H}(22 \mathrm{~B})-\mathrm{C}(22)-\mathrm{H}(22 \mathrm{C})$ fall at 109.5 degree showing the tetrahedral geometry. All the bond angles for the benzene ring was within the normal range while the bond angles for triazole ring exhibited slight deviation due to presence of strain in the five member ring structure. The $\mathrm{C}(5)-\mathrm{N}(1)-\mathrm{C}(2)$ and $\mathrm{N}(3)-\mathrm{C}(2)-\mathrm{N}(1)$ bond angle exhibited more distortion with the values close to the tetrahedral geometry in former case i.e., 108.62(12) while more shortness in later case $i$. e., 102.57(13). The lower values for the internal bond angles of triazole nucleus was observed for the $\mathrm{C}(2)-\mathrm{N}(3)-\mathrm{N}(4)$; 114.00(14) and $\mathrm{C}(5)-\mathrm{N}(4)-\mathrm{N}(3) ; 104.23(13)$ as compare to the external bond 
angles involving the triazole nucleus $i$. e., $\mathrm{C}(5)-\mathrm{N}(1)-\mathrm{N}(6) ; 122.02(12), \mathrm{C}(2)-\mathrm{N}(1)-\mathrm{N}(6) ; 128.33(13)$, $\mathrm{N}(3)-\mathrm{C}(2)-$ $\mathrm{S}(13) ; 128.50(12), \mathrm{N}(1)-\mathrm{C}(2)-\mathrm{S}(13) ; 128.92(11), \mathrm{C}(2)-\mathrm{N}(3)-\mathrm{H}(3) ; 126.2(14), \mathrm{N}(4)-\mathrm{N}(3)-\mathrm{H}(3) ; 119.7(14), \mathrm{N}(4)-\mathrm{C}(5)-$ $\mathrm{C}(14) ; 125.40(15)$ and $\mathrm{N}(1)-\mathrm{C}(5)-\mathrm{C}(14) ; 124.04(14)$. The bond angles for the imine junction was slightly shortened from the trigonal geometry as the experimental values for $\mathrm{C}(7)-\mathrm{N}(6)-\mathrm{N}(1)$ was 114.93(12). Meanwhile, very short bond angles was observed for the $\mathrm{C}(10)-\mathrm{S}(9)-\mathrm{C}(8)$; 91.57(9) due to presence of ring strain in the thiophene skeleton. Similarly, the shortening of the internal bond angles was observed for the thiophene nucleus i. e., $\mathrm{C}(11)-\mathrm{C}(10)-\mathrm{S}(9)$; 112.46(14), $\mathrm{C}(8)-\mathrm{C}(12)-\mathrm{C}(11)$; 112.42(15) and $\mathrm{C}(11)-\mathrm{C}(10)-\mathrm{S}(9)$; 112.46(14) while the external bond angles was close to the trigonal bond angles with the observed values of $\mathrm{C}(11)-\mathrm{C}(10)-\mathrm{H}(10) ; 123.8, \mathrm{~S}(9)-\mathrm{C}(10)-\mathrm{H}(10) ; 123.8$, $\mathrm{C}(10)-\mathrm{C}(11)-\mathrm{H}(11)$; 123.7, C(12)-C(11)-H(11); 123.7, C(8)-C(12)-H(12); 123.8, C(11)-C(12)-H(12); 123.8 and $\mathrm{C}(7)-\mathrm{C}(8)-\mathrm{S}(9) ; 122.53(12)$. Furthermore, the bond angles for the rest of molecules were within the normal range as shown in the Table 4.

\section{$\underline{\underline{\text { Table } 4}}$}

\section{Bioevaluation}

\section{a-Glucosidase inhibition activity of 2,5-disubstituted 1,3,4-oxadiazole derivatives 4a-k}

Diabetes mellitus is one of the most serious and chronic diseases associated with an increase in both obesity and ageing in the general population. The management of blood glucose levels after a meal is a critical strategy in the control of diabetes and its complications. One of the therapeutic approaches for decreasing postprandial hyperglycemia is to retard the absorption of glucose in blood return to its normal limits by inhibiting carbohydrate hydrolyzing enzymes (i.e., alpha-glucosidase) in the digestive organs [62]. Inhibitor drugs with $\alpha$-glucosidase inhibitory activities could be considered potential candidates to manage the early stages of hyperglycemia risk linked to type 2 diabetes. Based on these facts, we have synthesized a new series of 2,5-disubstituted 1,3,4oxadiazole derivatives $4 \mathbf{a}-\mathbf{k}$ and screened for their $\alpha$-glucosidase inhibition activity. Acarbose with $\mathrm{IC}_{50}$ value of $0.382 \pm 0.023 \mathrm{mM}$ was used as a reference inhibitor. The compounds $4 \mathbf{b}$ and $\mathbf{4 c}$ were the most potent inhibitor of $\alpha$ glucosidase with $\mathrm{IC}_{50}$ values of $0.641 \pm 0.12$ and $0.873 \pm 0.18 \mathrm{mM}$, respectively. The compound $\mathbf{4 b}$ has $4-\mathrm{OCH}_{3}$ group as substituent $\mathrm{R}$ while strong electron withdrawing 4-F group as substituent $\mathrm{X}$ with $\mathrm{n}$ values of 1 and $\mathrm{n}^{\prime}=2$ and the compound $\mathbf{4 c}$ exhibited electron donating $4-\mathrm{OCH}_{3}$ group as substituent $\mathrm{R}$ and electron withdrawing $3-\mathrm{F}$ group as substituent $\mathrm{X}$ with the same number of carbon atoms in between oxadiazole ring and side coupled aryl group. Meanwhile, the compound $\mathbf{4 d}$ with variation in the substituent $X$ as $2-\mathrm{F}$ group possess slight lower $\alpha$ glucosidase inhibition activity $i . e ., \mathrm{IC}_{50}$ values of $1.021 \pm 0.13 \mathrm{mM}$ but still the third most active compound among the series. All of the other compounds exhibited moderate to good $\alpha$-glucosidase inhibition activities with $\mathrm{IC}_{50}$ values ranging from $1.161 \pm 0.09$ to $1.44 \pm 0.05 \mathrm{mM}$. The least active compound among the series was $4 \mathbf{k}$ with $\mathrm{IC}_{50}$ values of $1.44 \pm 0.05 \mathrm{mM}$ and it possess $2-\mathrm{OCH}_{3}$ group as substituent $\mathrm{R}$ and $\mathrm{X}$ with the $\mathrm{n}=2$ and $\mathrm{n}^{\prime}=1$. In general, we have synthesized a new class of compounds with excellent anti-diabetic potential compare to that of reference drug. From these findings, it was concluded that the compounds substituted with electron withdrawing fluoro group were found to be more potent $\alpha$-glucosidase inhibitor while those with electron donating group exhibited moderate inhibition potential against tested bioassay. The results of $\alpha$-glucosidase inhibition assay for the 2,5-disubstituted 1,3,4-oxadiazole derivatives 4a-k are tabulated in Table $\mathbf{5}$.

\section{$\underline{\underline{\text { Table } 5}}$}

\section{Mechanism underlying inhibitory effect of compounds $4 b$ and $4 c$ on $\alpha$-glucosidase}

Since $4 \mathbf{b}$ and $\mathbf{4 c}$ were the most potent inhibitors in hand, we therefore further study mechanism underlying this inhibitory effect. The kinetic studies of the enzyme by the Lineweaver-Burk plot of $1 / \mathrm{V}$ versus $1 /[\mathrm{S}]$ in the presence of different concentrations of $\mathbf{4 b}$ and $\mathbf{4 c}$ gave a series of straight lines as shown in Fig. $\mathbf{5}$ and Fig. 6, respectively. The results of Fig. $\mathbf{5 a}$ showed that the compound $\mathbf{4 b}$ was a competitive inhibitor since increasing its concentration 
result the same $\mathrm{V}_{\max }$ but different $\mathrm{K}_{\mathrm{m}}$ values. The equilibrium constant $K_{i}$ for inhibitor binding with free enzyme was obtained from a plot of the inhibitor concentration [4b] versus the apparent Michaelis-Menten constant $\left(\mathrm{K}_{\mathrm{m}}\right)$ which is a linear as shown in the inset (Fig. $\mathbf{5 b}$ ). The obtained $K_{i}$ of $\mathbf{4 b}$ was $1.5 \times 10^{-4} \mathrm{M}$. The results of kinetic constants and the inhibition constants are summarized in Table $\mathbf{6}$.

\section{$\underline{\underline{\text { Fig. } 5 \text { and Table } 6}}$}

The results of Fig. 6a showed that by increasing the concentration of substrate yielded straight lines, all of which intersected within the second quadrant. The analysis showed that $\mathrm{V}_{\max }$ decreased with increasing $\mathrm{K}_{\mathrm{m}}$ in the presence of increasing concentrations of $\mathbf{4 c}$. This behavior of inhibitor compound $\mathbf{4 c}$ indicated that it inhibits $\alpha$-glucosidase by two different pathways; forming enzyme substrate inhibitor (ESI) complex in noncompetitive manner and enzyme inhibitor (EI) complex in competitive manner. The plot of slope against concentration of $\mathbf{4 c}$ showed EI dissociation constant values $K_{i}=2.5 \times 10^{-4}$ and ESI dissociation constant values of $K_{i^{\prime}}=4.0 \times 10^{-3}$ (Fig. $6 \mathbf{b}$ and $\mathbf{c}$ ). The lower dissociation constant $\left(\mathrm{K}_{\mathrm{i}}\right)$ (Table 7) pointed out stronger binding between enzyme and $\mathbf{4 c}$ which suggested preferred competitive over noncompetitive manners.

\section{Fig. 6 and Table 7}

Moreover, the concentration dependent enzyme inhibition potential was observed for the compounds $\mathbf{4 b}$ and $\mathbf{4 c}$ displaying the comparable $\alpha$-glucosidase inhibition with that of reference acarbose as shown in Fig. 7. However, the complete suppression of activity was not observed at any concentration of the inhibitor drug.

Fig. 7

\section{Molecular docking studies}

The ligand-protein binding modes and interactions are vital to understand the catalytic activity as the preferred orientation of ligands in 3D space into the protein binding site determines the activity of that ligand. Therefore, all the 30 conformations of ligands were docked inside the pocket despite the different level of binding energy and interactions with key residues. The docked poses were prioritized on the bases of binding free energy and ligand interaction. MOE ranked the docked conformations on the bases of binding energy (London $\mathrm{dG}$ ) and binding free energy in the "S" field. Detailed docking results are tabulated in Table T1 (Supporting information). These results are recorded on the bases of $2 \mathrm{D}$ interactions of the most preferred docked poses. All the preferred docked poses stacked beautifully inside the cavity.

\section{Fig. 8}

The most proffered docked poses of all the ligand showed that none of the ligand expressed any hydrogen bonding and Pi-H bonding with the side chain of the amino acids or back bone residues. Pi-Pi stacking is also established by only ligand $4 \mathrm{e}$ and $\mathbf{4 g}$ with HSD239. However $4 \mathrm{e}$ and $\mathbf{4 g}$ anchored over binding site by lesser number of the nonbonded interactions as compared to the ligands which showed better activity. All the ligands bind in active site through fewer non-bonded interaction with that of polar residues and hydrophobic residues. The finding obtained in docking computations is in close agreement with the experimental studies. Fig. 9 depicts the interaction of the most active ligands (4b, $\mathbf{4 c}$ and $\mathbf{4 d}$ ) with amino acid residues of active site in 2 dimensional (2D) space while 2-D interaction of all the docking poses of most preferred conformation of the series (4a-k) along with the control drug used in this studies are shown in Fig. S1. 
All the inhibitors showed binding free energy in S filed (-6.9187 to $-7.6047 \mathrm{Kcal} / \mathrm{mol})$ and binding energy, London dG in Escore-1 field $(-9.5093$ to $-9.7277 \mathrm{Kcal} / \mathrm{mol})$ in narrow range. In current studies the theoretical results synchronized well the experimental results. The compounds $\mathbf{4 b}, \mathbf{4 c}$ and $\mathbf{4 d}$ inhibited the catalytic activities of the $\alpha-$ glucosidase by fewer non-bonded interactions.

Fig. 9

Taking into account the peculiarities of the active-site residues in the $\alpha$-glucosidase catalysis, it can be concluded that some of the compounds of $\mathbf{4 a - k}$ series bind in active site through non-bonded interactions with Phe 157, Phe 177, Phe 300 Arg 312, Arg439 and Asp349.

\section{Urease inhibition activity of the triazole Schiff base derivatives 7a-k}

All the synthesized compounds $\mathbf{7} \mathbf{a}-\mathbf{k}$ were evaluated for their urease inhibition activities by employing thiourea as reference inhibitor with the $\mathrm{IC}_{50}$ value of $20.9 \pm 0.92 \mu \mathrm{M}$. All the $\mathrm{IC}_{50}$ values were recorded in triplicate and this data is presented as \pm SEM (standard error of the mean, $n=3$ ). The compounds $7 \mathbf{g}$ and $7 \mathbf{b}$ with the $\mathrm{IC}_{50}$ value of $8.02 \pm 0.59$ and $17.02 \pm 4.63 \mu \mathrm{M}$, respectively, were most potent with the higher inhibition in comparison to the $\mathrm{IC}_{50}$ value of the reference inhibitor thiourea as shown in Table $\mathbf{8}$. The compound $\mathbf{7 b}$ was further employed for the kinetic analysis in order to trace the mechanism underlying during the assay measurement. The Lineweaver-Burk plot represent the mixed type inhibition by the compound $\mathbf{7 b}$ with the EI and ESI dissociation constant values of 3 and $42 \mu \mathrm{M}$, respectively. The compounds $7 \mathbf{g}$ and $7 \mathbf{b}$ possessed the 2-ethylphenyl and 2-thiophenyl group as substituent $\mathrm{Y}$ while 3-bromo and 2-bromo group as substituent $\mathrm{R}$, respectively. There was no extra carbon between the triazole skeleton and the side coupled aryl group. The compound $7 \mathbf{h}$ with the $\mathrm{IC}_{50}$ value of $20.29 \pm 2.76 \mu \mathrm{M}$ exhibiting comparable urease inhibition potential with that of reference thiourea. The compound $\mathbf{7 h}$ has $3-\mathrm{OCH}_{3}$ group as substituent $\mathrm{R}$ while benzyl group as substituent $\mathrm{Y}$ representing that the replacement of bromo group at position 3 of side coupled aryl ring caused the reduction of urease inhibition activity of the resulting analogue. Meanwhile, the compounds $\mathbf{7 j}, \mathbf{7 e}, \mathbf{7} \mathbf{c}$ and $\mathbf{7 a}$ with the $\mathrm{IC}_{50}$ values of $25.45 \pm 3.09,35.71 \pm 6.28,39.30 \pm 5.03$ and $42.59 \pm 4.35 \mu \mathrm{M}$, respectively, showed moderate urease inhibition potential. In all of these compounds, there is no bromo substitution over side coupled aryl rings. The activities of rest of compounds were in the range of $77.34 \pm$ 7.92 to $186.8 \pm 16.95 \mu \mathrm{M}$. The compound $7 \mathrm{~d}$ with the $\mathrm{IC}_{50}$ value of $186.8 \pm 16.95 \mu \mathrm{M}$ was the least active compound among the investigated series. This compound possessed the fluoro group at position 2 of the side coupled aryl ring and 2-pyrroyl substitution as the group Y connected to the central nucleus via Schiff base spacer. The overall structure activity relationship of the synthesized compounds in comparison to their inhibition potential reveals that the presence of bromo substituent at position 3 and 2 of the aryl ring as well as 2-ethylphenyl group coupled via imine formation with the central triazole nucleus impart potent inhibitory characters to the compounds. The methoxy substitution to the side coupled aryl group induces the moderate inhibition while the least inhibition efficacy was observed for the analogues possessing strong electron withdrawing fluoro substitution on side coupled aryl ring. On the other hand, the 2-ethylphenyl group as substituent $\mathrm{Y}$ coupled to the central triazole skeleton via imine linkage was found more effective in imparting inhibitory characters toward urease while 2-pyrroyl group reduced the activities of the compounds.

\section{$\underline{\underline{T a b l e ~} 8}$}

\section{Mechanism underlying inhibitory effect of compound $7 \mathrm{~b}$}

The kinetic investigation for the urease inhibition analysis was accomplished by the Lineweaver-Burk plot of $(1 / V)$ versus $1 /[\mathrm{S}]$ in the presence of different concentrations of inhibitor (7b) which gave a series of straight lines as shown in Fig. 10. Furthermore, the EI dissociation constant $(\mathrm{Ki})$ and ESI dissociation constant $(\mathrm{Ki})$ were determined 
to gain insightful pathway by secondary replots. By increasing the concentration of substrate (urea) gave a family of straight lines, all of which intersected within the second quadrant. The analysis showed that $\mathrm{V}_{\max }$ (reaction velocity) decreased with increasing $\mathrm{K}_{\mathrm{m}}$ (Michaelise-Menten constant) in the presence of increasing concentrations of compound (7b). This behavior of compound (7b) indicated that it is a mixed type inhibitor with respect to the substrate urea exhibiting the $K i$ and $K i^{\prime}$ values of 3 and $42 \mu \mathrm{M}$, respectively, as shown in Fig. 10 (b, c) [51].

\section{Fig. 10}

\section{Molecular docking studies}

Molecular docking of 7a-k series into the crystal structure of jack bean urease was performed by using the MOE program. The most favorable docking conformations of all the compounds were stacked well inside the active site cavity. The active site was architectured with both the hydrophobic and hydrophilic amino acids. The hydrophobic part was constructed by Leu523, Ala 636, Ala440, Met 637 and Met 588 while hydrophilic portion contained Arg439, His 492, Asp494, His519, His593, Glu493and Arg609 amino acids. It has been observed that two Ni ions played a significant role by bridging the amino acids residues inside the active site. All the 30 conformations of ligands were docked inside the pocket despite the different level of binding energy and interactions with amino acids residues inside the active site. The docked poses were prioritized on the bases of binding free energy and ligand interaction. MOE ranked the docked conformations on the bases of binding energy (London $\mathrm{dG}$ ) and binding free energy in the "S" field. Detailed docking results are tabulated in Table T2 (Supporting information). These results are recorded on the bases of $2 \mathrm{D}$ interactions of the most preferred docked poses. All the preferred docked poses stacked beautifully inside the cavity as shown in Fig. 11.

\section{Fig. 11}

An insight into the binding mode analysis of the most preferred docked conformations revealed that the ligands $\mathbf{7 b}$, $7 \mathrm{~g}$ and $7 \mathrm{~h}$ were tightly anchored over the active-site cavity through hydrogen bonding. A very significant hydrogen bonding interactions with the Met637, Arg439 and Met588, has been noticed. Ni ions played a significant role in orientation of the residues inside the close vicinity of active site through chelation as shown in Fig. 12. The Fig. 12 depicted the 3-D interaction of the most significant inhibitors $\mathbf{7 b}, \mathbf{7} \mathbf{g}$ and $\mathbf{7 h}$. The binding pattern adopted by these ligands made them engage the active site residues, using typical hydrogen bonds to anchor tightly with the side chain and backbone of the enzyme. The phenyl ring found to be involved in the arene-H interaction in case of the most active ligands. Only ligands $\mathbf{7} \mathbf{c}$ showed arene-arene stacking.

\section{Fig. 12}

All the inhibitors showed binding free energy in S filed $(-5.0312$ to $-6.0760 \mathrm{Kcal} / \mathrm{mol})$ and binding energy, London dG in Escore-1 field $(-8.5129$ to $-9.7104 \mathrm{Kcal} / \mathrm{mol})$ in narrow range. The theoretical results synchronized well the experimental results in current studies. The compounds which didn't show any significant interaction were found inactive in experimental screening such as $\mathbf{7 i}$ and $\mathbf{7 d}$. The compounds $\mathbf{7 b}, \mathbf{7 g}$ and $\mathbf{7 h}$ presented remarkable interactions with amino acid residues in active site these were found to exhibit far better activity than that of standard drug in experimental screening. This fact could be attributed to the multiple strong binding interactions by these ligands with amino acid residues of the jack bean urease as compared to the standard drug thiourea. The docking mode of the most potent compounds, $7 \mathbf{b}, 7 \mathrm{~g}$ and $\mathbf{7 h}$ inhibited the catalytic activities of the urease by anchoring firmly through strong hydrogen bonding, $\mathrm{Pi}-\mathrm{H}$ interactions and tremendous polar interactions in active site. Fig. 13 depicts the interaction of the most active ligands $(\mathbf{7 b}, 7 \mathbf{g}$ and $7 \mathbf{h})$ with key residues of active site in 2 dimensional (2D) space while 2-D interaction of all the docking poses of most preferred conformation of the series (7a to 7k) along with the control drug used in this studies are shown in Fig. S2 (Supporting information). 


\section{Fig. 13}

Taking into account the distinctiveness of the active-site residues in the urease catalysis, it can be concluded that some of the compounds of 7a-k made strong contacts with the side chains of urease residues, which was reflected in their enhanced affinity to the Arg439, Ala 636, Ala440, Met 637, His592, Asp494, Arg439, Met588 and Met637 residues $[63,64]$. Besides being directly involved in the architecture of the active site, the nickel ions had a vital role in positioning other key residues in the active site appropriately for the catalysis through various interactions such as hydrogen bonding and chelation.

\section{Conclusion}

In summary, we have synthesized the series of substituted oxadiazole derivatives $\mathbf{4 a - k}$ as well as triazole Schiff base derivatives 7a-k. The structures of these compounds were characterized by FT-IR, ${ }^{1} \mathrm{H}$ NMR, ${ }^{13} \mathrm{C}$ NMR and single crystal X-ray diffraction analysis. The X-ray single crystal structure of compound 7k showed that molecule predominantly exist in thione conformation. The synthesized compounds were evaluated for bioactivities and kinetic analysis. The oxadiazole derivatives $\mathbf{4 a - k}$ were found as potent $\alpha$-glucosidase inhibitors while the Schiff base derivatives $\mathbf{7 a - k}$ exhibited considerable potential toward urease inhibition. The compounds $\mathbf{4 b}$ and $\mathbf{4 c}$ were the most potent inhibitor of $\alpha$-glucosidase with the $\mathrm{IC}_{50}$ values of $0.641 \pm 0.12$ and $0.873 \pm 0.18 \mathrm{mM}$, respectively, exhibiting more inhibition potency in comparison to the $\mathrm{IC}_{50}$ values of reference acarbose $\left(\mathrm{IC}_{50}\right.$ value of $\left.0.382 \pm 0.023 \mathrm{mM}\right)$. Meanwhile, the compound $\mathbf{4 d}$ was screened as $3^{\text {rd }}$ most active compound among the tested series with the $\mathrm{IC}_{50}$ values of $1.021 \pm 0.13 \mathrm{mM}$. The inhibition kinetics analyzed by Lineweaver-Burk plots against $\alpha-$ glucosidase revealed that the compound $\mathbf{4 b}$ act as competitive while $\mathbf{4 c}$ as mixed inhibitors with the inhibition constant values of $1.5 \times 10^{-4}$ and $4.0 \times 10^{-3} \mathrm{M}$, respectively. In case of Schiff base series $\mathbf{7 a - k}$, the compounds $7 \mathbf{g}$ and $7 \mathbf{b}$ with the $\mathrm{IC}_{50}$ values of $8.02 \pm 0.59$ and $17.02 \pm 4.63 \mu \mathrm{M}$, respectively, showed excellent inhibition potential toward the urease even higher inhibition than the reference thiourea $\left(\mathrm{IC}_{50}=20.9 \pm 0.92 \mu \mathrm{M}\right)$. For mechanistic insight, the compound 7b was further employed for the kinetic analysis via Lineweaver-Burk plot which represents the mixed type inhibition by the compound $\mathbf{7 b}$ alongside the EI and ESI dissociation constant values of 3 and $42 \mu \mathrm{M}$, respectively. The $3^{\text {rd }}$ most active urease inhibitor among the tested series was $7 \mathbf{h}$ with the $\mathrm{IC}_{50}$ value of $20.29 \pm 2.76 \mu \mathrm{M}$ exhibiting comparable urease inhibition with that of reference thiourea. Meanwhile, the compounds 7j, 7e, 7c and 7a with the $\mathrm{IC}_{50}$ values of $25.45 \pm 3.09,35.71 \pm 6.28,39.30 \pm 5.03$ and $42.59 \pm 4.35 \mu \mathrm{M}$, respectively, showed moderate urease inhibition activity. The commendable urease inhibition was observed by the designed Schiff bases of 1,2,4-triazole in comparison to previously reported isolated triazole based molecules or Schiff base derivatives where there was no direct connection of imine bond with that of triazole skeleton. Moreover, according to the systematic investigation on the binding mode of the $\alpha$-glucosidase and urease inhibition by the compounds $\mathbf{4 a - k}$ and

$\mathbf{7 a - k}$, respectively, it could be deduced that the compounds $\mathbf{4 b}, \mathbf{4 c}, \mathbf{7 b}, \mathbf{7 g}$ and $\mathbf{7 h}$ were competitive inhibitors targeting amino acids in the active site of the corresponding protein. The docking results and experimental screening results were found in close agreement.

\section{Acknowledgements}

This work was supported by a grant from Mid-Career Researcher Program (NRF-2016R1A2B4016552) through the National Research Foundation of Korea (NRF) funded by the Ministry of Science, ICT \& Future Planning(MSIP). 
We are extremely grateful for the cooperation of Dr. Charles Dennis Hall and Prof Alan Roy Katritzky (late) (University of Florida) for the MOE software license. Department of Energy, United State of America through Grant No. DE-SC0001717 is gratefully acknowledged.

\section{References}

1. D. Kovacs, G. Motyan, J. Wolfling, I. Kovacs, I. Zupko, E. Frank, Bioorg. Med. Chem. Lett. 24 (2014) $1265-1268$.

2. S.A. Shahzad, M. Yar, M. Bajda, L. Shahzadi, Z.A. Khan, S.A.R. Naqvi, S. Mutahir, N. Mahmood, K.M. Khan, Bioorg Chem 60 (2015) 37-41.

3. R.K. Dani, M.K. Bharty, S.K. Kushawaha, O. Prakash, V.K. Sharma, R.N. Kharwar, R.K. Singh, N.K. Singh, Polyhedron. 81 (2014) 261-272.

4. S.D. Joshi, S.R. Dixit, U.A. More, K.V.S.N. Raju, R. Narayan, T.M. Aminabhavi, V.H. Kulkarni, Med. Chem. Res. 23 (2014) 4542-4558.

5. H. Kandemir, C. Ma, S.K. Kutty, D.S. Black, R. Griffith, P.J. Lewis, N. Kumar, Bioorg. Med. Chem. 22 (2014) 1672-1679.

6. L. Li, H. Ding, B. Wang, S. Yu, Y. Zou, X. Chai, Q. Wu, Bioorg. Med. Chem. Lett. 24 (2014) 192-194.

7. A. Kakanejadifard, F. Azarbani, Z. Saki, S. Kakanejadifard, A. Zabardasti, Spectrochim Acta A. 132 (2014) 700-705.

8. I. Khan, A. Ibrar, N. Abbas, Arch. Pharm. Chem. Life Sci. 347 (2014) 1-20.

9. N. Siddiqui, M.J. Akhtar, M.S. Yar, P. Ahuja, W. Ahsan, S. Ahmed, Med. Chem. Res. 23 (2014) 49154925.

10. A. Kamal, A.B. Shaik, S. Polepalli, V.S. Reddy, G.B. Kumar, S. Gupta, K.V.S.R. Krishna, A. Nagabhushana, R.K. Mishra, N. Jain, Org. Biomol. Chem. 12 (2014) 7993-8007.

11. S. Bansal, M. Bala, S.K. Suthar, S. Choudhary, S. Bhattacharya, V. Bhardwaj, S. Singla, A. Joseph, Eur. J. Med. Chem. 80 (2014) 167-174.

12. Y. Zhou, B. Wang, F. Di, L. Xiong, N. Yang, Y. Li, Z. Li, Bioorg. Med. Chem. Lett. 24 (2014) 2295-2299.

13. T.J. Lukas, G.E. Schiltz, H. Arrat, K. Scheidt, T. Siddique, Bioorg. Med. Chem. Lett. 24 (2014) 15321537.

14. B.R. Liao, H.B. He, L.L. Yang, L.X. Gao, L. Chang, T. Tang, J.Y. Li, J. Li, F. Yang, Eur. J. Med. Chem. 83 (2014) 15-25.

15. F. Zhang, X.L. Wang, J. Shi, S.F. Wang, Y. Yin, Y.S. Yang, W.M. Zhang, H.L. Zhu, Bioorg. Med. Chem. 22 (2014) 468-471.

16. H. Kashtoh, S. Hussain, A. Khan, S.M. Saad, J.A.J. Khan, K.M. Khan, S. Perveen, M.I. Choudhary, Bioorg. Med. Chem. 22 (2014) 5454-5465.

17. C. Xiao, Q. Huang, Journal of Asia-Pacific Entomology. 17 (2014) 251-256.

18. S. Valente, D. Trisciuoglio, T.D. Luca, A. Nebbioso, D. Labella, A. Lenoci, C. Bigogno, G. Dondio, M. Miceli, G. Brosch, D.D. Bufalo, L. Altucci, A. Mai, J. Med. Chem. 57 (2014) 6259-6265.

19. S.A. Shahzad, M. Yar, M. Bajda, B. Jadoon, Z.A. Khan, S.A.R. Naqvi, A.J. Shaikh, K. Hayat, A. Mahmmod, N. Mahmood, S. Filipek, Bioorg. Med. Chem. 22 (2014) 1008-1015.

20. J. Choi, S.K. Lee, J. Bae, S.K. Chang, Tetrahedron Lett. 55 (2014) 5294-5297.

21. N. Deshapande, N.S. Belavagi, S.I. Panchamukhi, M.H. Rabinal, I.A.M. Khazi, Optical Materials. 37 (2014) 516-519.

22. L. Guo, W.K. Hagmann, S. He, Z. Lai, J. Liu, R.P. Nargund, S.K. Shah, Q.T. Truong, United States Patent, Jun. 17, 2014, No. US 8,754, 099 B2

23. R.V. Shingalapur, K.M. Hosamani, R.S. Keri, M.H. Hugar, Eur. J. Med. Chem. 45 (2010) 1753-1759.

24. S. Nazreen, M.S. Alam, H. Hamid, M.S. Yar, S. Shafi, A. Dhulap, P. Alam, M.A.Q. Pasha, S. Bano, M.M. Alam, S. Haider, Y. Ali, C. Kharbanda, K.K. Pillai, Eur. J. Med. Chem. 87 (2014) 175-185.

25. C. Vilanova, S.T. Gutierrez, S.D. Oltra, J. Murga, E. Falomir, M. Carda, J.A. Marco, Eur. J. Med. Chem. 87 (2014) 125-130.

26. L.Y. Ma, L.P. Pang, B. Wang, M. Zhang, B. Hu, D.Q. Xue, K.P. Shao, B.L. Zhang, Y. Liu, E. Zhang, H.M. Liu, Eur. J. Med. Chem. 86 (2014) 368-380.

27. G.E.A.A. Abuo-Rahma, M. Abdel-Aziz, N.A. Farag, T.S. Kaoud, Eur. J. Med. Chem. 83 (2014) 398-408. 
28. K.M. Krishna, B. Inturi, G.V. Pujar, M.N. Purohit, G.S. Vijaykumar, Eur. J. Med. Chem. 84 (2014) 516529.

29. K. Kumar, B. Pradines, M. R. Madamet, Amalvict, V. Kumar, Eur. J. Med. Chem. 86 (2014) 113-121.

30. A.T. Mavrova, D. Wesselinova, J.A. Tsenov, L.A. Lubenov, Eur. J. Med. Chem. 86 (2014) 676-683.

31. R. Romagnoli, P.G. Baraldi, M.K. Salvador, F. Prencipe, V. Bertolasi, M. Cancellieri, A. Brancale, Hamel, E.I. Castagliuolo, F. Consolaro, E. Porcu, G. Basso, G. J. Viola, Med. Chem. 57 (2014) 6795-6808.

32. T. Plech, B. Kapron, J.J. Luszczki, A. Paneth, A. Siwek, M. Kolaczkowski, M. Zolnierek, G. Nowak, Eur. J. Med. Chem. 86 (2014) 690-699.

33. Y.P. Xu, J. Qin, S.M. Sun, T.T. Liu, X.L. Zhang, S.S. Qian, H.L. Zhu, Inorganica Chimica Acta. 423 (2014) 469-476.

34. P.E. Rodriguez, E.M. Clavijo, A.T. Carmona, A.J.M. Vargas, I. Robina, Org. Biomol. Chem. 12 (2014) 5898-5904.

35. H. Khanmohammadi, M.H. Abnosi, A. Hosseinzadeh, M. Erfantalab, Spectrochim Acta A. 71 (2008) 1474-1480.

36. S. Xiaohong, L. Yuanfa, C. Shuzhe, C. Bang, J. Yingqi, Z. Zhengfang, Chinese Journal of Chemistry, 27 (2009) 949-952.

37. M.S. Karthikeyan, D.J. Prasad, B. Poojary, K.S. Bhat, B.S. Holla, N.S. Kumari, Bioorg. Med. Chem. 14 (2006) 7482-7489.

38. B.N.P. Kumar, K.N. Mohana, L. Mallesha, J. Fluorine Chem. 156 (2013) 15-20.

39. Y. Unver, K. Sancak, F. Celik, E. Birinci, M. Kucuk, S. Soylu, N.A. Burnaz, Eur. J. Med. Chem. 84 (2014) 639-650.

40. H. Bayrak, A. Demirbas, S.A. Karaoglu, N. Demirbas, Eur. J. Med. Chem. 44 (2009) 1057-1066.

41. Z.H. Chohan, M. Hanif, Appl. Organometal. Chem. 25 (2011) 753-760.

42. D. Ji, J.R. Lu, B.W. Lu, C.W. Xin, J.B. Mu, J.F. Li, C.Y. Peng, X.R. Bao, Bioorg. Med. Chem. Lett. 23 (2013) 1997-2000.

43. F. Zhang, Q. Wen, S.F. Wang, B.S. Karim, Y.S. Yang, J.J. Liu, W.M. Zhang, H.L. Zhu, Bioorg. Med. Chem. Lett. 24 (2014) 90-95.

44. M.K. Awad, R.M. Issa, F.M. Atlam, Materials and Corrosion. 60 (2009) 813-819.

45. Moorthy, N.S.H.N. Vittal, U.B. Karthikeyan, C. Thangapandian, V. Venkadachallam, A.P. Trivedi, P. Arabian J. Chem. DOI: 10.1016/j.arabjc.2013.12.021.

46. Z. Amtul, M. Rasheed, M.I. Choudhary, S. Rosanna, K.M. Atta-ur-Rahman, Biochem. Biophys. Res. Commun. 319 (2004) 1053-1063.

47. A. Ibrar, I. Khan, N. Abbas, Arch. Pharm. Chem. Life Sci. 346 (2013) 423-446.

48. M.Y. Mentese, H. Bayrak, Y. Uygun, A. Mermer, S. Ulker, S.A. Karaoglu, N. Demirbas, Eur. J. Med. Chem. 67 (2013) 230-242.

49. I. Khan, S. Ali, S. Hameed, N.H. Rama, M.T. Hussain, A. Wadood, R. Uddin, Z. Ul-Haq, A. Khan, S. Ali, M.I. Choudhary, Eur. J. Med. Chem. 45 (2010) 5200-5207.

50. O. Bekircan, E. Mentese, S. Ulker, C. Kucuk, Arch. Pharm. Chem. Life Sci. 347 (2014) 387-397.

51. E. Rattanangkool, P. Kittikhunnatham, T. Damsud, S. Wacharasindhu, P. Phuwapraisirisan, Eur. J. Med. Chem. 66 (2013) 296-304.

52. O. Abid, T.M. Babar, F.I. Ali, S. Ahmed, A. Wadood, N.H. Rama, R. Uddin, Z. Haq, A. Khan, M.I. Choudhary, ACS Med. Chem. Lett. 1 (2010) 145-149.

53. Q. Wang, L. Qiu, X. Chen, K.K. Song, Y. Shy Q.X. Chen, Bioorg. Med. Chem. Lett. 15 (2007) 1565-1571.

54. Molecular Operating Environment (MOE), 2013.08; Chemical Computing Group Inc., 1010Sherbooke St. West, Suite \#910, Montreal, QC, Canada, H3A 2R7, 2015.

55. A. Balasubramanian, K. Ponnuraj, J. Mol. Biol. 400 (2010) 274-283.

56. T.A. Halgren,. J. Comput. Chem. 17 (1996) 587-615.

57. J. Farukh, S.S. Aaliya, F.M. Qaiser, S. Sobia, I. Lubna, A. Nighat, S.P. Siva, A.L. Farzana, RSC Advances (under review).

58. M.W. Weatherburn, Phenol-hypochlorite reaction for determination of ammonia. Anal. Chem. 39 (1967) 971-974.

59. K.M. Khan, F. Rahim, A. Khan, M. Shabeer, S. Hussain, W. Rehman, T. Taha, M. Khan, S. Perveen, M.I. Choudhary, Bioorg. Med. Chem. 22 (2014) 4119-4123. 
60. Z. Amtul, N. Kausar, C. Follmer, R.F. Rozmahel, Atta-Ur-Rahman, S.A. Kazmi, M.S. Shekhani, J.L. Eriksen, K.M. Khan, M.I. Choudhary, Bioorg Med Chem. 14 (2006) 6737-6744.

61. F.H. Allen, O. Kennard, D.G.J. Watson, (1987) Chem. Soc. Perkin Trans II. S1-S19; DOI:10.1039/P298700000S1

62. J.A. Sneha, S. Chaudhari, Asian J Pharm Clin Res. 4 (2011) 99-102.

63. M.A.S. Aslam, M. Shams-ul, S. Mohammad, S. Aamer, I. Jamshed, Eur. J. Med. Chem. 46 (2011) 54735479.

64. S. Aamer, Z. Sumera, P. Arshid, M. Amara, S. Mohammad, I. Jamshed Iqbal. Med. Chem. Res. 22 (2013) 3653-3662. 


\section{$\underline{\underline{\text { Schemes, Figures and Tables along with captions }}}$}

$\underline{\underline{\text { Scheme } 1}}$

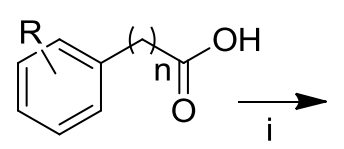

1<smiles>[R]c1cccc(NC(=O)Cl)c1</smiles>

2<smiles>[R]c1cccc(CC(=O)NN)c1</smiles>

3<smiles>[X]c1ccc([Al]c2nnc([Al]c3cccc([R])c3)o2)cc1</smiles>

4a-k<smiles>[Y]C=Nn1c(Nc2ccc([R])cc2)n[nH]c1=S</smiles>

Scheme 1 Synthesis of target compounds 4a-k and 7a-k: Reagents and conditions: (i) $\mathrm{POCl}_{3}, \mathrm{ClCH}_{2} \mathrm{CH}_{2} \mathrm{Cl}_{1} \mathrm{reflux}$ $3 \mathrm{~h}$; (ii) hydrazine hydrate, TEA, MeCN, reflux 3 h; (iii) substituted aromatic acid, $\mathrm{POCl}_{3}, \mathrm{reflux}, 3 \mathrm{~h}$; (iv) $\mathrm{CS}_{2}$, $\mathrm{KOH}$, methanol, stirring, $0{ }^{\circ} \mathrm{C}, 1 \mathrm{~h}$; (v) Hydrazine hydrate (80\%), water, reflux, $10-12 \mathrm{~h}$; (vi) different substituted triazole derivatives, substituted aldehydes, methanol, microwave pulse (10 $\mathrm{min})$.

\section{$\underline{\underline{\text { Scheme } 2}}$}<smiles>[Y]C=Nn1c([Al]c2ccccc2)n[nH]c1=S</smiles>

(a)

Thione tautomer<smiles>C1CCCCCC1</smiles>

T<smiles>[Y]C=Nn1c(S)nnc1Nc1ccccc1</smiles>

Thiol tautomer

Scheme 2 Thione-thiol tautomerism in the compounds $\mathbf{7 a - k}$ 


\section{$\underline{\text { Fig. } 1}$}
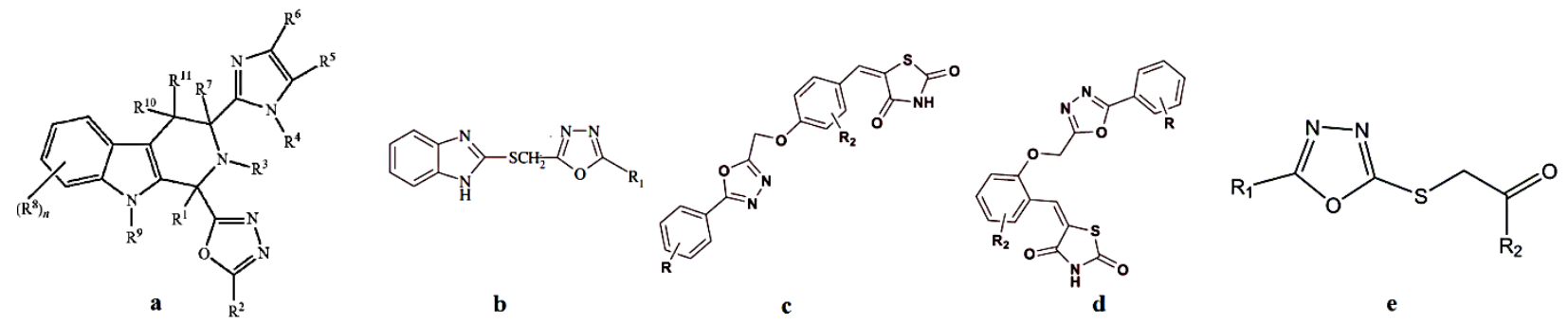

Fig. 1 Molecular structure of known anti-diabetic compounds

\section{$\underline{\underline{\text { Fig. } 2}}$}

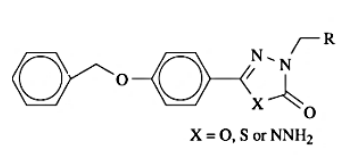

f

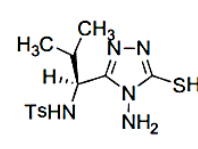

g

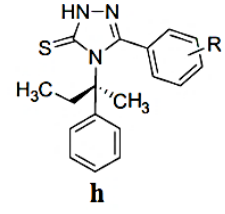

h

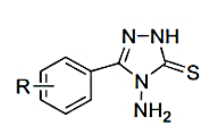

i
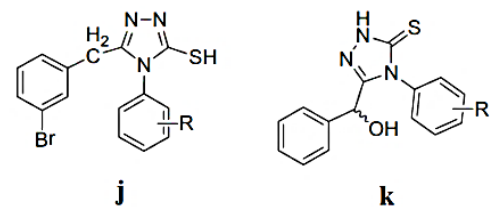

k
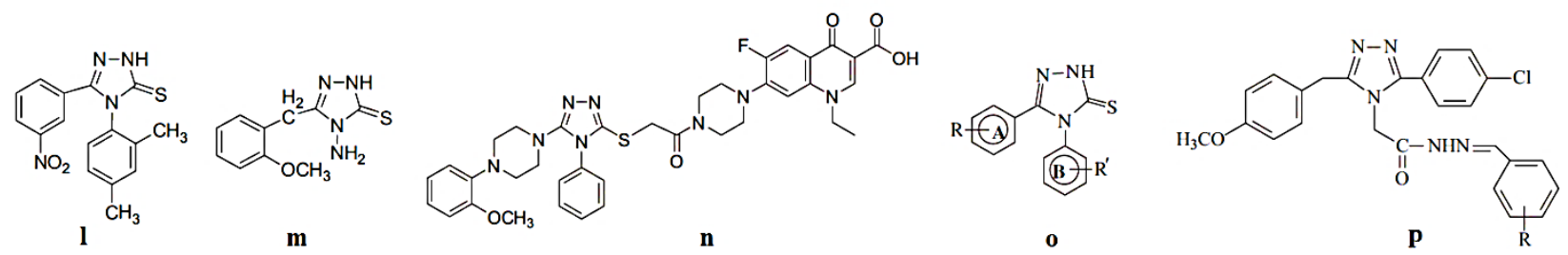

Fig. 2 Molecular structure of the reported 1,2,4-triazole based urease inhibitors.

\section{$\underline{\underline{\text { Fig. 3 }}}$}

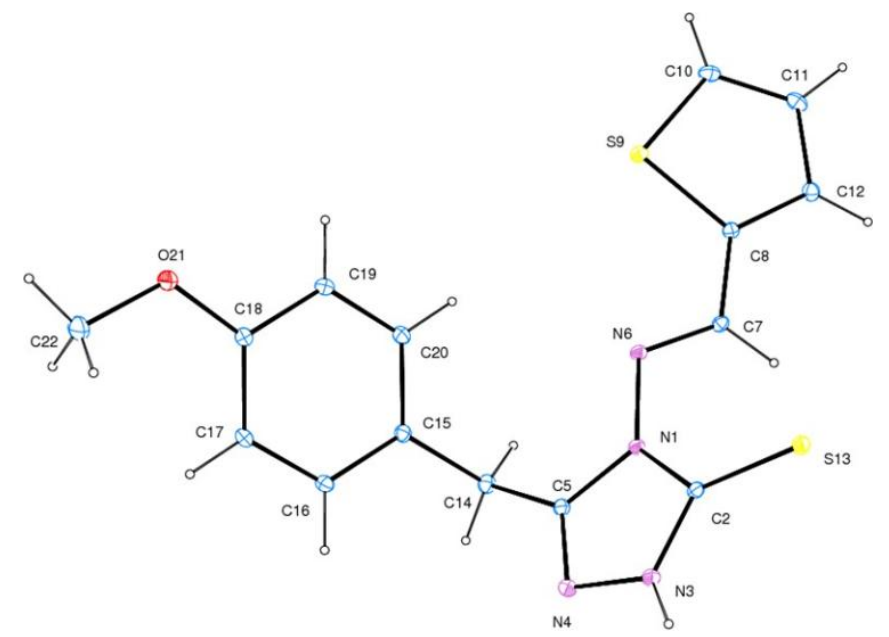


Fig. 3 Single crystal X-ray structure of $7 \mathbf{k}$ with the atom-numbering scheme

$\underline{\underline{\text { Fig. } 4}}$

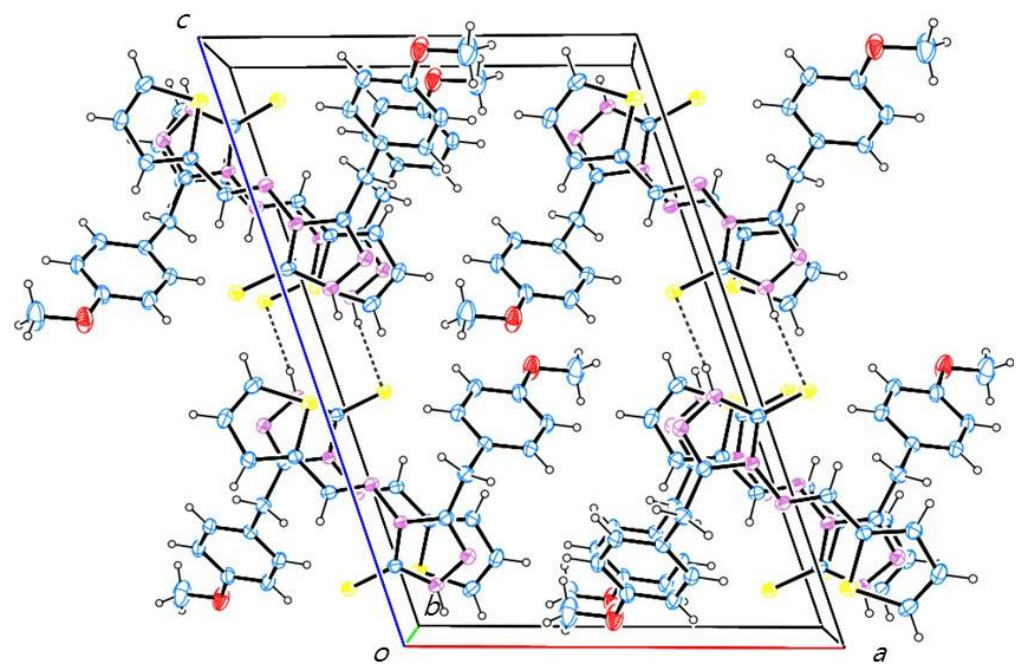

Fig. 4 The packing diagram for $7 \mathbf{k}$ in the regular crystal lattice; the dash line represent the intermolecular hydrogen bonding within the compound $7 \mathbf{k}$.

\section{$\underline{\text { Fig. } 5}$}

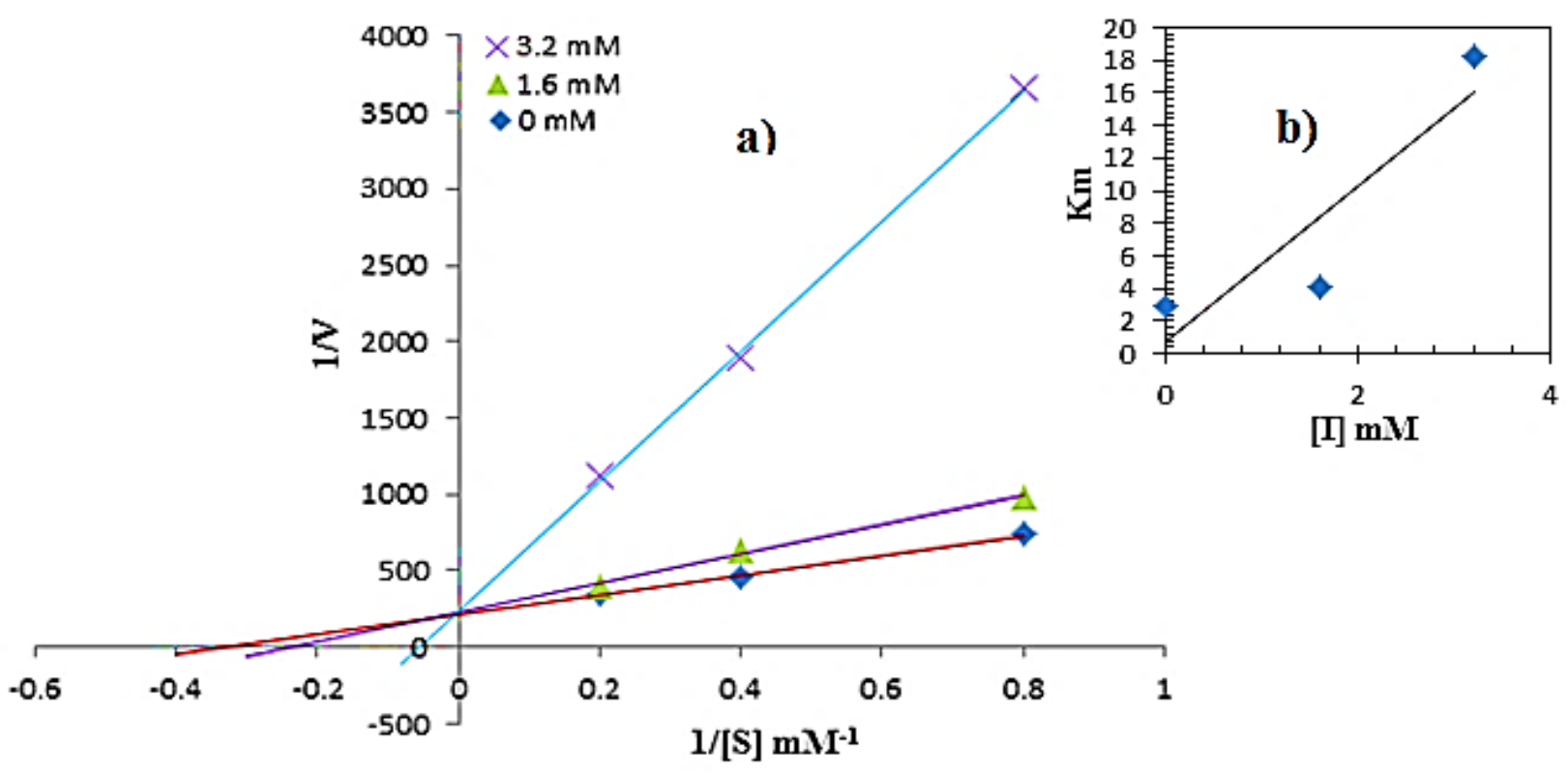

Fig. 5 Lineweaver-Burk plots for $\mathbf{4 b}$ against $\alpha$-glucosidase inhibition assay; (a) concentration of $\mathbf{4 b}$ was $0 \mathrm{mM}, 1.6$ $\mathrm{mM}$ and $3.2 \mathrm{mM}$; substrate concentration was $1.25 \mathrm{mM}, 2.5 \mathrm{mM}$ and $5 \mathrm{mM}$, respectively; (b) Inset graph represents 
the plot of $\mathrm{K}_{\mathrm{m}}$ versus the concentration of $\mathbf{4 b}$ in order to determine the inhibition constant $\left(K_{i}\right)$. The line was drawn using linear least-squares fitting method.

\section{$\underline{\text { Fig. } 6}$}
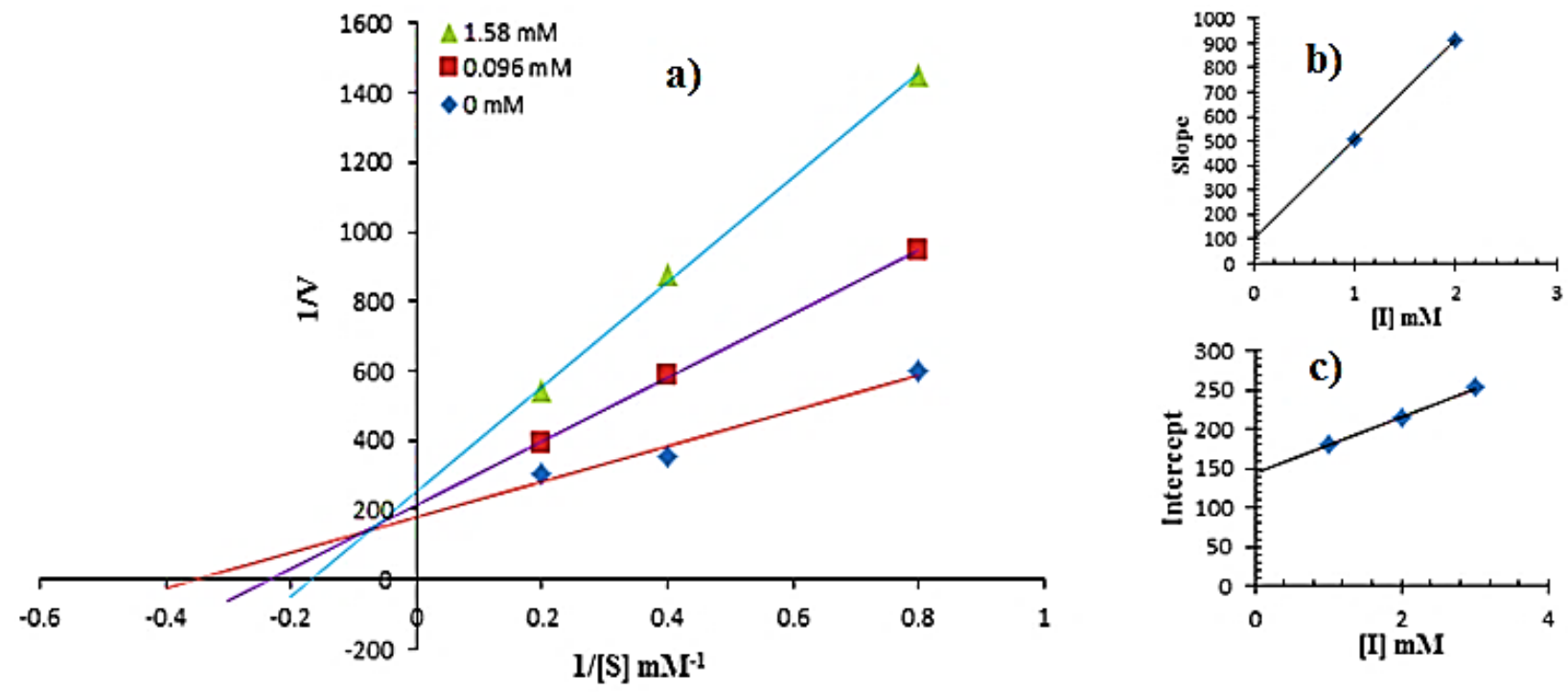

Fig. 6 Lineweaver-Burk plots against $\alpha$-glucosidase inhibition in the presence of compound $4 \mathbf{c}$; the concentrations of $4 \mathrm{c}$ was $0 \mathrm{mM}, 0.096 \mathrm{mM}$ and $1.58 \mathrm{mM}$, respectively while substrate concentration was $1.25 \mathrm{mM}, 2.5 \mathrm{mM}$ and $5 \mathrm{mM}$, respectively; the insets represent the plot of the slope and the vertical intercepts $\left(1 / \mathrm{V}_{\max }\right.$ app) versus $4 \mathrm{c}$ concentrations in order to determine inhibition constants which was drawn by using linear least squares fitting method (inset graph $b$ and $c$ ).

\section{Fig. 7}
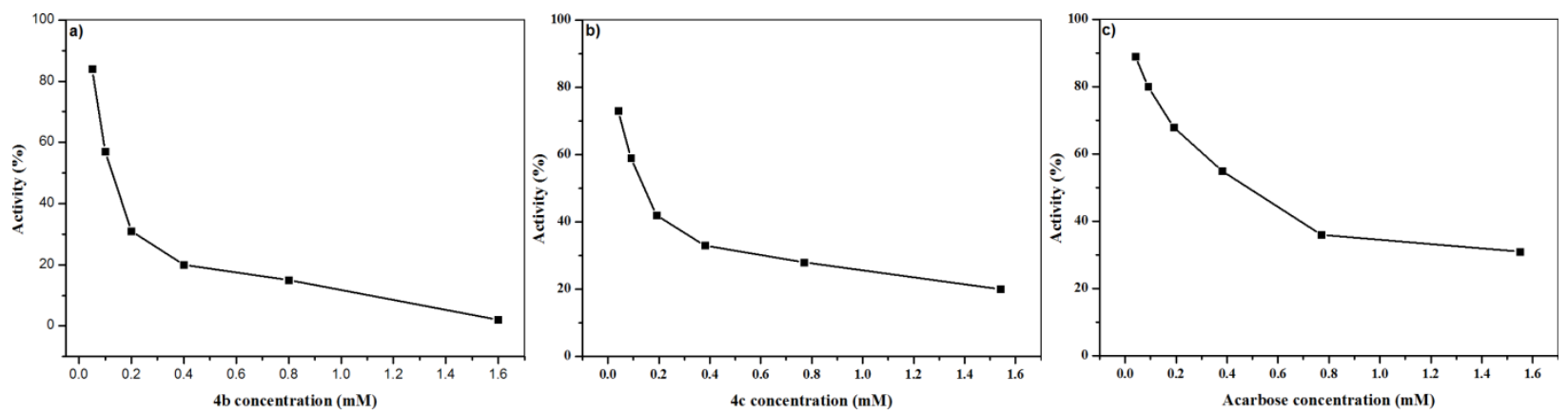

Fig. 7 Concentration-dependent $\alpha$-Glucosidase inhibition by the compounds $\mathbf{4 b}, \mathbf{4 c}$ and reference Acarbose 
Fig. 8
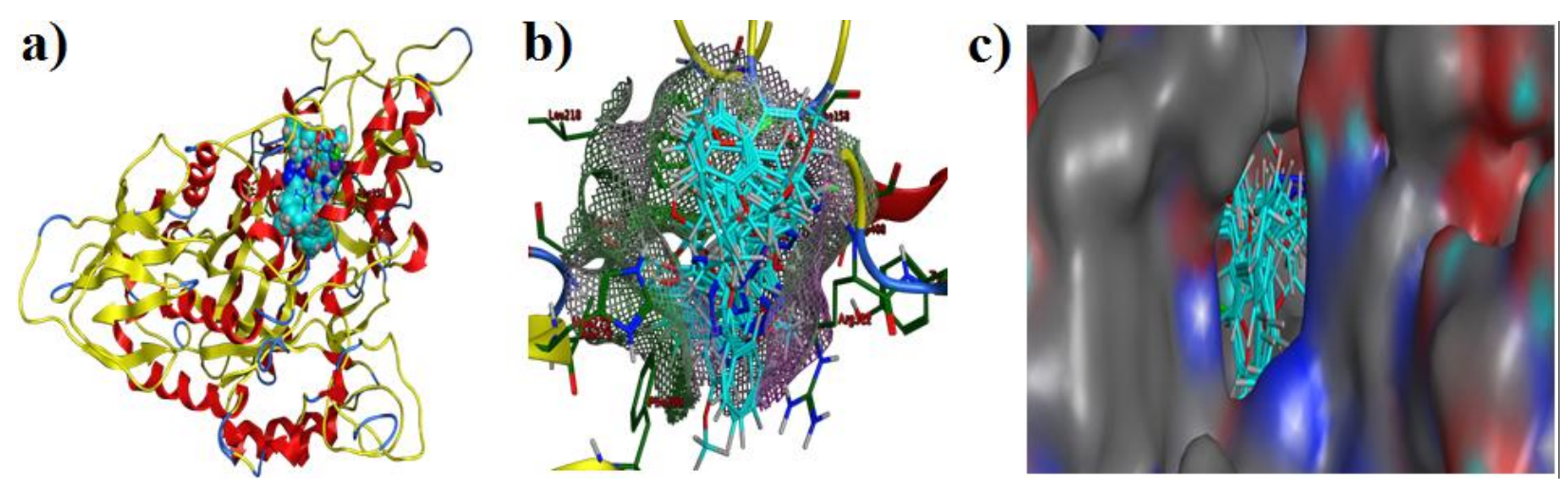

Fig. 8: Superimposition of the ligands inside the active site of homology modeled $\alpha$-glucosidase; (a) Homology model of the yeast $\alpha$-glucosidase (blue, yellow and red color) showing the ligand cluster (cyan color; stick mode) into the binding site. The green color indicates the amino acid residues (labeled in red) surrounding the binding site; (b) Close view of the active site, pocket is marked with surfaces (line mode); c) Binding site cavity with the ligand cluster (amino acid residues are shown in elemental color, solid surfaces).

Fig. 9

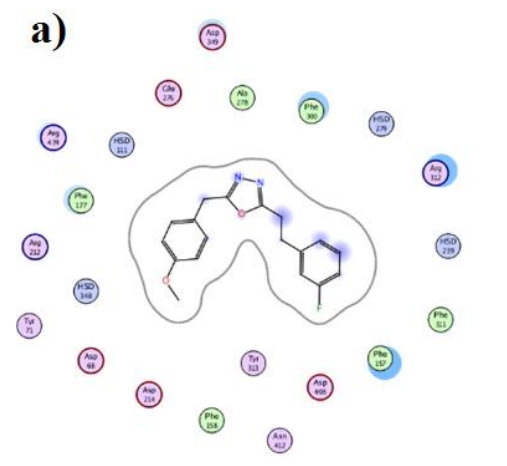

b)

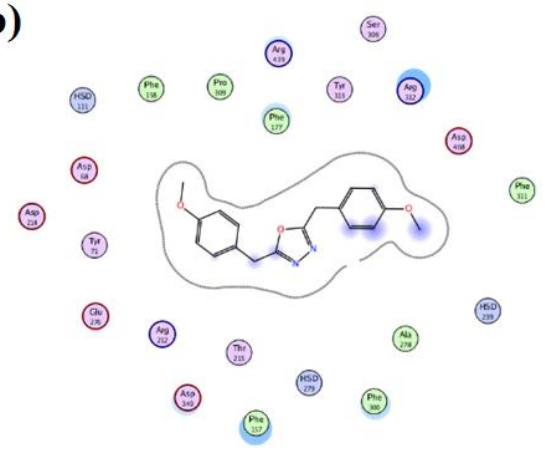

c)

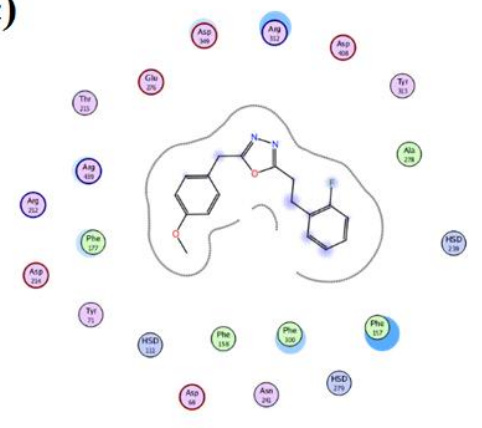

Fig. 9: Docked poses of the most ligands inside the active site in 2-D space; a) 4b; b) 4c and c) 4d. (Legend about color and rest of the pattern is given in Fig. S1 in supporting information). 
Fig. 10
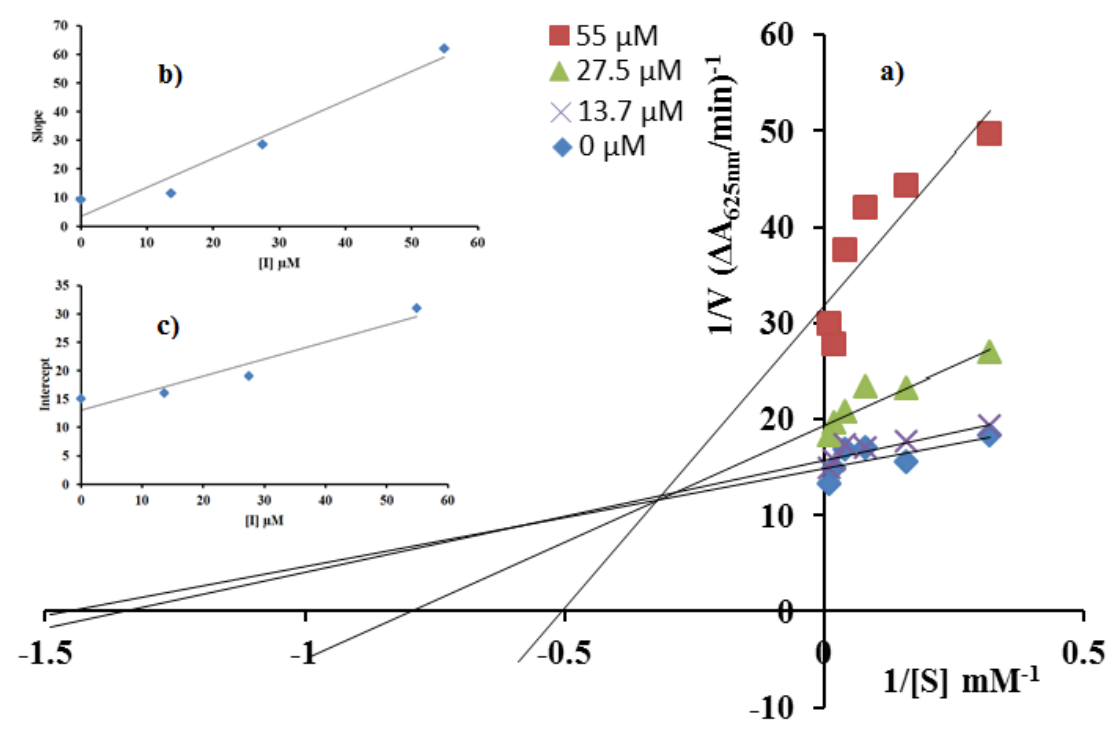

Fig. 10. The double reciprocal Lineweaver-Burk plots for the inhibition of urease in the presence of compound (7b) (a); the concentrations of $7 \mathbf{b}$ were $0,13.7,27.5$ and $55 \mu \mathrm{M}$, respectively using the urea as substrate. The urea concentrations were $3.12,6.25,12.5,25,50$ and $100 \mathrm{mM}$, respectively. The insets represent the plot of the slope (inset, b); and the vertical intercepts (inset, c), versus inhibitor (7b) concentrations in order to find out the inhibition constants. The lines were drawn using linear least squares fit.

\section{Fig. 11}



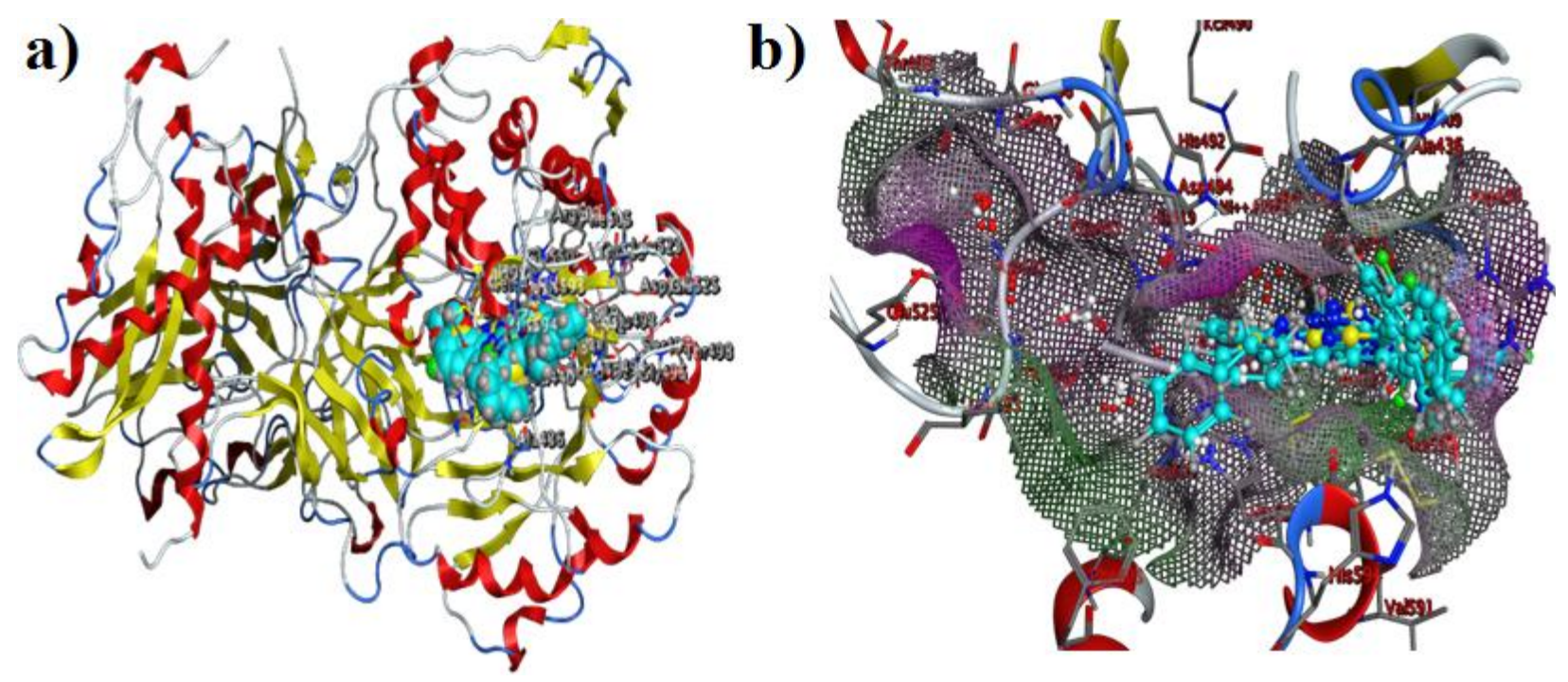

Fig. 11. Superimposition of the ligands inside the active site; (a) Overlaying of all the minimum energy docked poses inside the pocket. Ligands are shown in cyan color in stick mode while key residues are shown in green color in stick mode. Backbone receptor is shown in cartoon and ribbon form. (b) Close view of the active site, pocket is marked with surfaces (line mode).

Fig. 12 
a)

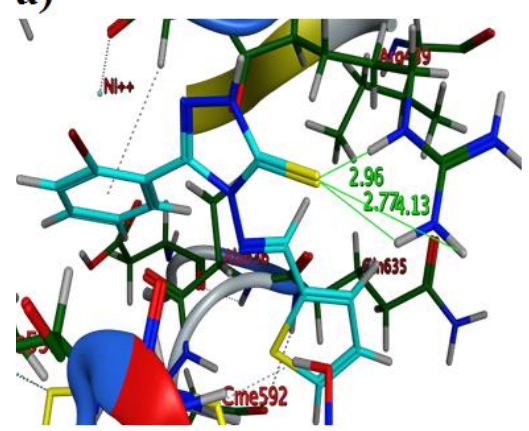

d)

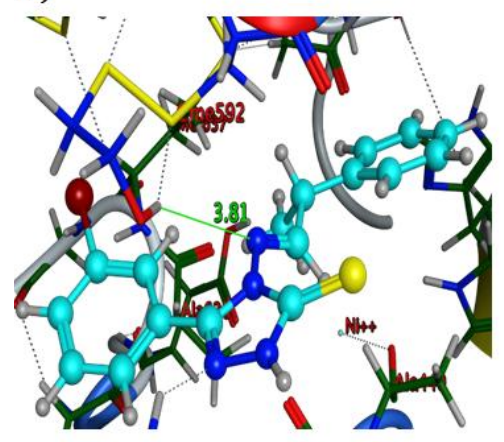

g)

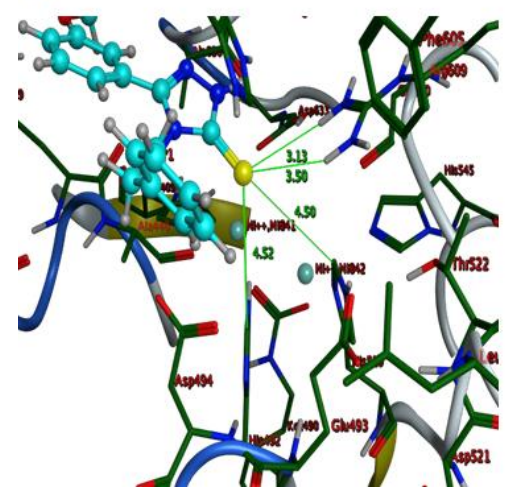

b)

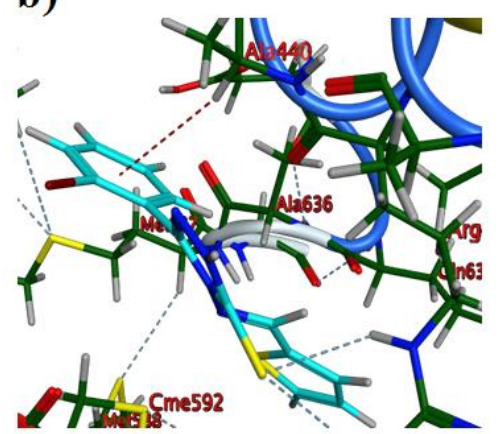

e)

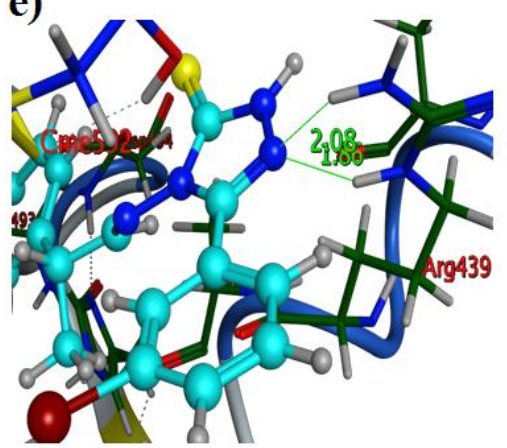

h)

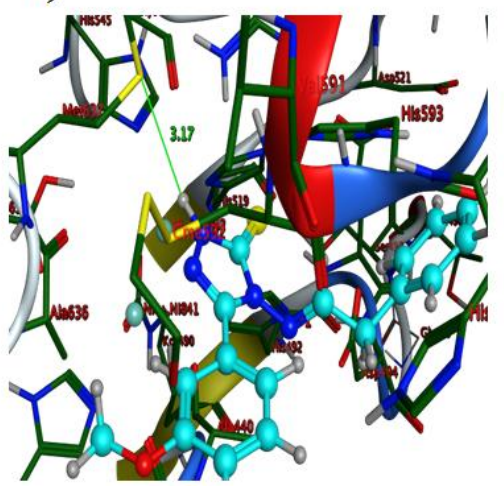

c)

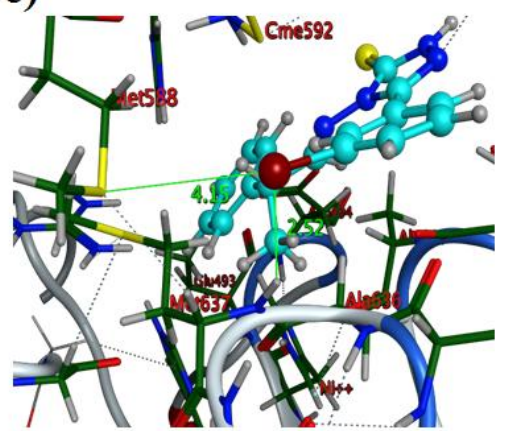

f)

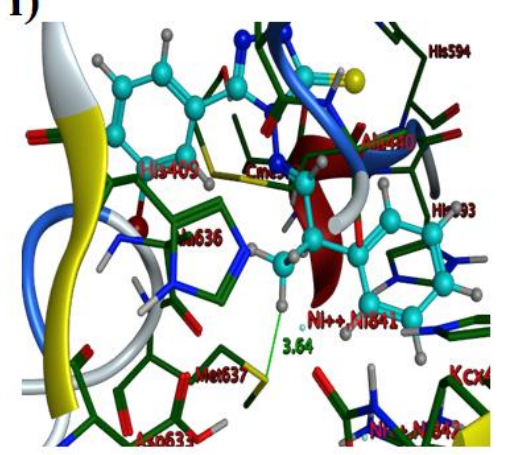

i)

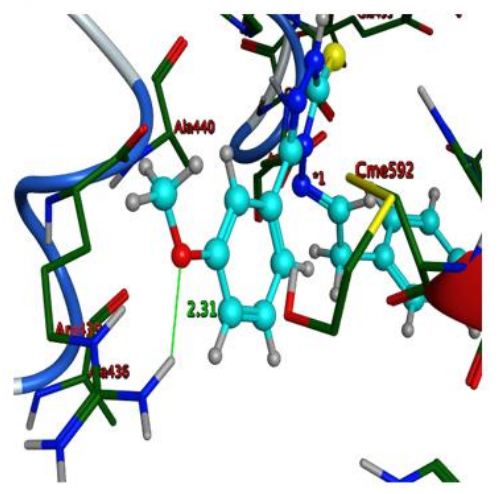

Fig. 12. 3D Interaction of ligand $\mathbf{2 a}(\mathbf{a}-\mathbf{b})$ and $7 \mathbf{a}(\mathbf{e}-\mathbf{f}) \mathbf{8 a}(\mathbf{g}-\mathbf{h})$. Ligands are shown in cyan color (stick $\mathrm{n}$ ball mode), key residues of the active site are shown in green and element color (stick mode) nickel ions are shown as cyan dots. Hydrogen bonding and other interactions are shown as solid green color lines, marked with the distance. Interaction of amino acids with each other is shown in cyan color dotted lines; a) Interaction of S atom with atoms Arg 439; b) $\mathrm{Pi}-\mathrm{H}$ contact of phenyl ring with Ala440, (shown in red colored dotted line) 7a (c-f); c) Interaction of $\mathrm{Br}$ atom with Met588 and Met637; d) Hydrogen bonding of ligand atom with Cme592 (shown in blue color); e) Hydrogen bonding of ligand atom with Arg439; f) Contact of Hydrogen with S atom of Met $637 \mathbf{8 h}(\mathbf{g - i})$; g) Interaction of S atom with side chain of Arg 609, Met 493 and Glu439; h) Hydrogen bonding of ligand atoms with Met637; i) Hydrogen bonding of ligand atoms with Arg439

Fig. 13 
a)

(Mer

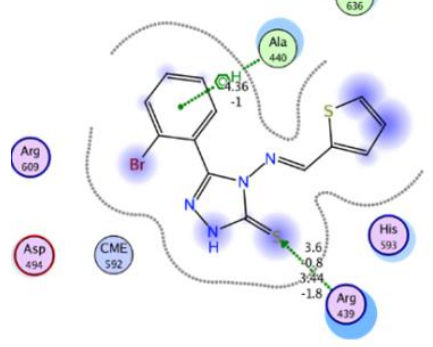

b)

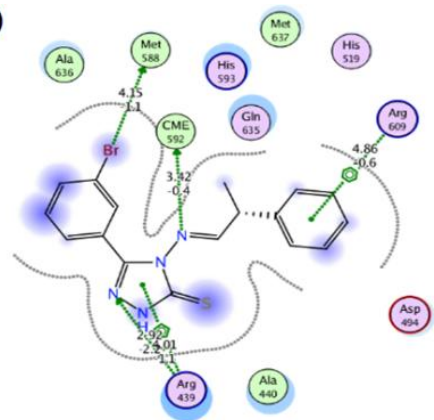

c)

(:0)

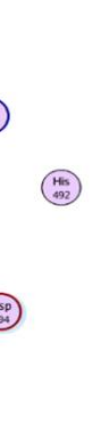

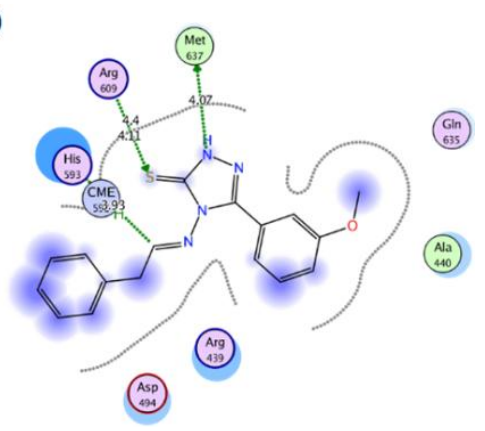

Fig. 13: Docked poses of the most ligands inside the active site in 2-D space; a) $7 \mathbf{b}$, b) $7 \mathbf{g}$ and c) $7 \mathbf{h}$. Interactions are shown in green dotted lines (Legend about color and rest of the pattern is given in Fig. S2 in Supporting information).

\section{Tables along with captions}

\section{$\underline{\underline{\text { Table } 1}}$}

Table $\mathbf{1}$ Crystallographic data for compound $\mathbf{7 k}$

\begin{tabular}{llll}
\hline Description & Experimental values & Description & Experimental values \\
\hline \hline Empirical formula & $\mathrm{C}_{15} \mathrm{H}_{14} \mathrm{~N}_{4} \mathrm{OS}_{2}$ & Cell formula unit, $\mathrm{z}$ & 4 \\
\hline
\end{tabular}




\begin{tabular}{llll}
\hline Formula weight & 330.42 & Density (calculated) & $1.374 \mathrm{mg} / \mathrm{m}^{3}$ \\
Temperature & $296(2) \mathrm{K}$ & Absorption coefficient & $0.340 \mathrm{~m}^{2} \mathrm{M}^{-1}$ \\
Crystal system & monoclinic & F(000) & 688 \\
Space group & P 21/c & Theta min. & $2.37^{\circ}$ \\
a & $12.330(8) \AA$ & Theta max. & 28.01 \\
$\mathrm{~b}$ & $7.540(5) \AA$ & Color & Yellow \\
$\mathrm{c}$ & $18.134(12) \AA$ & Crystal size, Max. & $0.20 \mathrm{~mm}^{3}$ \\
$\alpha$ & $90(1)^{\circ}$ & Crystal size, Mid. & $0.18 \mathrm{~mm}^{3}$ \\
$\beta$ & $108.713(9)$ & Crystal size, Min. & $0.15 \mathrm{~mm}^{3}$ \\
$\gamma$ & $90(1)^{\circ}$ & Diff. radiation wavelength & $0.71073 \mathrm{~nm}$ \\
Cell volume & $1596.9(18) \AA^{3}$ & Refinement method & Full-matrix least-squares on $\mathrm{F}^{2}$ \\
\hline
\end{tabular}

\section{$\underline{\underline{\text { Table } 2}}$}

Table $\mathbf{2}$ The bond length $[\AA]$ and bond angle $\left[{ }^{\circ}\right]$ for hydrogen bond of $\mathbf{7 k}$

\begin{tabular}{lllll}
\hline $\mathrm{D}-\mathrm{H} \ldots \mathrm{A}$ & $\mathrm{d}(\mathrm{D}-\mathrm{H})[\AA]$ & $\mathrm{d}(\mathrm{H} \ldots \mathrm{A})[\AA]$ & $\mathrm{d}(\mathrm{D} \ldots \mathrm{A})[\AA]$ & $<(\mathrm{DHA})\left[{ }^{\circ}\right]$ \\
\hline \hline $\mathrm{N}(3)-\mathrm{H}(3) \ldots \mathrm{S}(13) \# 1$ & $0.85(2)$ & $2.48(2)$ & $3.323(2)$ & $170.8(19)$ \\
\hline
\end{tabular}

Symmetry transformations used to generate equivalent atoms: \#1 -x,-y+1,-z

\section{$\underline{\underline{\text { Table } 3}}$}

Table 3 Bond Length $[\AA]$ for $\mathbf{7 k}$

\begin{tabular}{llll}
\hline Bond & Length $[\AA]$ & Bond & Length $[\AA]$ \\
\hline \hline $\mathrm{N}(1)-\mathrm{C}(5)$ & $1.378(2)$ & $\mathrm{C}(12)-\mathrm{H}(12)$ & 0.9300 \\
$\mathrm{~N}(1)-\mathrm{C}(2)$ & $1.3811(19)$ & $\mathrm{C}(14)-\mathrm{C}(15)$ & $1.520(2)$ \\
$\mathrm{N}(1)-\mathrm{N}(6)$ & $1.4037(18)$ & $\mathrm{C}(14)-\mathrm{H}(14 \mathrm{~A})$ & 0.9700 \\
$\mathrm{C}(2)-\mathrm{N}(3)$ & $1.338(2)$ & $\mathrm{C}(14)-\mathrm{H}(14 \mathrm{~B})$ & 0.9700 \\
$\mathrm{C}(2)-\mathrm{S}(13)$ & $1.6795(18)$ & $\mathrm{C}(15)-\mathrm{C}(16)$ & $1.386(2)$
\end{tabular}




\begin{tabular}{llll}
$\mathrm{N}(3)-\mathrm{N}(4)$ & $1.377(2)$ & $\mathrm{C}(15)-\mathrm{C}(20)$ & $1.391(2)$ \\
$\mathrm{N}(3)-\mathrm{H}(3)$ & $0.85(2)$ & $\mathrm{C}(16)-\mathrm{C}(17)$ & $1.387(3)$ \\
$\mathrm{N}(4)-\mathrm{C}(5)$ & $1.299(2)$ & $\mathrm{C}(16)-\mathrm{H}(16)$ & 0.9300 \\
$\mathrm{C}(5)-\mathrm{C}(14)$ & $1.496(2)$ & $\mathrm{C}(17)-\mathrm{C}(18)$ & $1.386(3)$ \\
$\mathrm{N}(6)-\mathrm{C}(7)$ & $1.281(2)$ & $\mathrm{C}(17)-\mathrm{H}(17)$ & 0.9300 \\
$\mathrm{C}(7)-\mathrm{C}(8)$ & $1.439(2)$ & $\mathrm{C}(18)-\mathrm{O}(21)$ & $1.362(2)$ \\
$\mathrm{C}(7)-\mathrm{H}(7)$ & 0.9300 & $\mathrm{C}(18)-\mathrm{C}(19)$ & $1.391(3)$ \\
$\mathrm{C}(8)-\mathrm{C}(12)$ & $1.370(2)$ & $\mathrm{C}(19)-\mathrm{C}(20)$ & $1.376(3)$ \\
$\mathrm{C}(8)-\mathrm{S}(9)$ & $1.7242(17)$ & $\mathrm{C}(19)-\mathrm{H}(19)$ & 0.9300 \\
$\mathrm{~S}(9)-\mathrm{C}(10)$ & $1.703(2)$ & $\mathrm{C}(20)-\mathrm{H}(20)$ & 0.9300 \\
$\mathrm{C}(10)-\mathrm{C}(11)$ & $1.345(3)$ & $\mathrm{O}(21)-\mathrm{C}(22)$ & $1.412(3)$ \\
$\mathrm{C}(10)-\mathrm{H}(10)$ & 0.9300 & $\mathrm{C}(22)-\mathrm{H}(22 \mathrm{~A})$ & 0.9600 \\
$\mathrm{C}(11)-\mathrm{C}(12)$ & $1.415(3)$ & $\mathrm{C}(22)-\mathrm{H}(22 \mathrm{~B})$ & 0.9600 \\
$\mathrm{C}(11)-\mathrm{H}(11)$ & 0.9300 & $\mathrm{C}(22)-\mathrm{H}(22 \mathrm{C})$ & 0.9600 \\
\hline
\end{tabular}

\section{$\underline{\underline{\text { Table } 4}}$}

Table 4 Bond angles $\left[{ }^{\circ}\right]$ for $\mathbf{7 k}$

\begin{tabular}{llll}
\hline Bond & Angles $\left[^{\circ}\right]$ & Bond & Angles [ $\left.{ }^{\circ}\right]$ \\
\hline \hline $\mathrm{C}(5)-\mathrm{N}(1)-\mathrm{C}(2)$ & $108.62(12)$ & $\mathrm{C}(5)-\mathrm{C}(14)-\mathrm{H}(14 \mathrm{~A})$ & 109.3 \\
$\mathrm{C}(5)-\mathrm{N}(1)-\mathrm{N}(6)$ & $122.02(12)$ & $\mathrm{C}(15)-\mathrm{C}(14)-\mathrm{H}(14 \mathrm{~A})$ & 109.3 \\
$\mathrm{C}(2)-\mathrm{N}(1)-\mathrm{N}(6)$ & $128.33(13)$ & $\mathrm{C}(5)-\mathrm{C}(14)-\mathrm{H}(14 \mathrm{~B})$ & 109.3 \\
$\mathrm{~N}(3)-\mathrm{C}(2)-\mathrm{N}(1)$ & $102.57(13)$ & $\mathrm{C}(15)-\mathrm{C}(14)-\mathrm{H}(14 \mathrm{~B})$ & 109.3 \\
$\mathrm{~N}(3)-\mathrm{C}(2)-\mathrm{S}(13)$ & $128.50(12)$ & $\mathrm{H}(14 \mathrm{~A})-\mathrm{C}(14)-\mathrm{H}(14 \mathrm{~B})$ & 108.0 \\
$\mathrm{~N}(1)-\mathrm{C}(2)-\mathrm{S}(13)$ & $128.92(11)$ & $\mathrm{C}(16)-\mathrm{C}(15)-\mathrm{C}(20)$ & $117.75(16)$ \\
\end{tabular}




\begin{tabular}{llll}
$\mathrm{C}(2)-\mathrm{N}(3)-\mathrm{N}(4)$ & $114.00(14)$ & $\mathrm{C}(16)-\mathrm{C}(15)-\mathrm{C}(14)$ & $121.11(15)$ \\
$\mathrm{C}(2)-\mathrm{N}(3)-\mathrm{H}(3)$ & $126.2(14)$ & $\mathrm{C}(20)-\mathrm{C}(15)-\mathrm{C}(14)$ & $121.09(15)$ \\
$\mathrm{N}(4)-\mathrm{N}(3)-\mathrm{H}(3)$ & $119.7(14)$ & $\mathrm{C}(15)-\mathrm{C}(16)-\mathrm{C}(17)$ & $122.07(16)$ \\
$\mathrm{C}(5)-\mathrm{N}(4)-\mathrm{N}(3)$ & $104.23(13)$ & $\mathrm{C}(15)-\mathrm{C}(16)-\mathrm{H}(16)$ & 119.0 \\
$\mathrm{~N}(4)-\mathrm{C}(5)-\mathrm{N}(1)$ & $110.55(13)$ & $\mathrm{C}(17)-\mathrm{C}(16)-\mathrm{H}(16)$ & 119.0 \\
$\mathrm{~N}(4)-\mathrm{C}(5)-\mathrm{C}(14)$ & $125.40(15)$ & $\mathrm{C}(18)-\mathrm{C}(17)-\mathrm{C}(16)$ & $119.17(16)$ \\
$\mathrm{N}(1)-\mathrm{C}(5)-\mathrm{C}(14)$ & $124.04(14)$ & $\mathrm{C}(18)-\mathrm{C}(17)-\mathrm{H}(17)$ & 120.4 \\
$\mathrm{C}(7)-\mathrm{N}(6)-\mathrm{N}(1)$ & $114.93(12)$ & $\mathrm{C}(16)-\mathrm{C}(17)-\mathrm{H}(17)$ & 120.4 \\
$\mathrm{~N}(6)-\mathrm{C}(7)-\mathrm{C}(8)$ & $119.99(13)$ & $\mathrm{O}(21)-\mathrm{C}(18)-\mathrm{C}(17)$ & $124.93(17)$ \\
$\mathrm{N}(6)-\mathrm{C}(7)-\mathrm{H}(7)$ & 120.0 & $\mathrm{O}(21)-\mathrm{C}(18)-\mathrm{C}(19)$ & $115.55(16)$ \\
$\mathrm{C}(8)-\mathrm{C}(7)-\mathrm{H}(7)$ & 120.0 & $\mathrm{C}(17)-\mathrm{C}(18)-\mathrm{C}(19)$ & $119.52(17)$ \\
$\mathrm{C}(12)-\mathrm{C}(8)-\mathrm{C}(7)$ & $126.60(14)$ & $\mathrm{C}(20)-\mathrm{C}(19)-\mathrm{C}(18)$ & $120.45(17)$ \\
$\mathrm{C}(12)-\mathrm{C}(8)-\mathrm{S}(9)$ & $110.87(12)$ & $\mathrm{C}(20)-\mathrm{C}(19)-\mathrm{H}(19)$ & 119.8 \\
$\mathrm{C}(7)-\mathrm{C}(8)-\mathrm{S}(9)$ & $122.53(12)$ & $\mathrm{C}(18)-\mathrm{C}(19)-\mathrm{H}(19)$ & 119.8 \\
$\mathrm{C}(10)-\mathrm{S}(9)-\mathrm{C}(8)$ & $91.57(9)$ & $\mathrm{C}(19)-\mathrm{C}(20)-\mathrm{C}(15)$ & $121.05(16)$ \\
$\mathrm{C}(11)-\mathrm{C}(10)-\mathrm{S}(9)$ & $112.46(14)$ & $\mathrm{C}(19)-\mathrm{C}(20)-\mathrm{H}(20)$ & 119.5 \\
$\mathrm{C}(11)-\mathrm{C}(10)-\mathrm{H}(10)$ & 123.8 & $\mathrm{C}(15)-\mathrm{C}(20)-\mathrm{H}(20)$ & 119.5 \\
$\mathrm{~S}(9)-\mathrm{C}(10)-\mathrm{H}(10)$ & 123.8 & $\mathrm{C}(18)-\mathrm{O}(21)-\mathrm{C}(22)$ & $118.44(17)$ \\
$\mathrm{C}(10)-\mathrm{C}(11)-\mathrm{C}(12)$ & $112.68(16)$ & $\mathrm{O}(21)-\mathrm{C}(22)-\mathrm{H}(22 \mathrm{~A})$ & 109.5 \\
$\mathrm{C}(10)-\mathrm{C}(11)-\mathrm{H}(11)$ & 123.7 & $\mathrm{O}(21)-\mathrm{C}(22)-\mathrm{H}(22 \mathrm{~B})$ & 109.5 \\
$\mathrm{C}(12)-\mathrm{C}(11)-\mathrm{H}(11)$ & 123.7 & $\mathrm{H}(22 \mathrm{~A})-\mathrm{C}(22)-\mathrm{H}(22 \mathrm{~B})$ & 109.5 \\
$\mathrm{C}(8)-\mathrm{C}(12)-\mathrm{C}(11)$ & $112.42(15)$ & $\mathrm{O}(21)-\mathrm{C}(22)-\mathrm{H}(22 \mathrm{C})$ & 109.5 \\
$\mathrm{C}(8)-\mathrm{C}(12)-\mathrm{H}(12)$ & 123.8 & $\mathrm{H}(22 \mathrm{~A})-\mathrm{C}(22)-\mathrm{H}(22 \mathrm{C})$ & 109.5 \\
$\mathrm{C}(11)-\mathrm{C}(12)-\mathrm{H}(12)$ & 123.8 & $\mathrm{H}(22 \mathrm{~B})-\mathrm{C}(22)-\mathrm{H}(22 \mathrm{C})$ & 109.5 \\
$\mathrm{C}(5)-\mathrm{C}(14)-\mathrm{C}(15)$ & $111.56(13)$ & $\mathrm{H}(22 \mathrm{~B})-\mathrm{C}(22)-\mathrm{H}(22 \mathrm{C})$ & 109.5 \\
\hline
\end{tabular}

\section{$\underline{\underline{\text { Table } 5}}$}

Table 5 Results of $\alpha$-glucosidase inhibition assay for the 2,5-disubstituted 1,3,4-oxadiazole derivatives 4a-k.

\begin{tabular}{llllll}
\hline Comp. & $\mathbf{R}$ & $\mathbf{X}$ & $\mathbf{n}$ & $\mathbf{n}^{\prime}$ & $\begin{array}{l}\boldsymbol{\alpha} \text {-Glucosidase inhibition bioassay } \\
\left\{\mathbf{I C}_{\mathbf{5 0}}(\mathbf{m M}) \pm \mathbf{S E M}^{\mathbf{a}} \boldsymbol{\}}\right.\end{array}$ \\
\hline \hline $\mathbf{4 a}$ & $4-\mathrm{OCH}_{3}$ & $4-\mathrm{OCH}_{3}$ & 1 & 1 & $1.161 \pm 0.09$ \\
$\mathbf{4 b}$ & $4-\mathrm{OCH}_{3}$ & $4-\mathrm{F}$ & 1 & 2 & $0.641 \pm 0.12$ \\
\hline
\end{tabular}




\begin{tabular}{llllll}
\hline $\mathbf{4 c}$ & $4-\mathrm{OCH}_{3}$ & $3-\mathrm{F}$ & 1 & 2 & $0.873 \pm 0.18$ \\
$\mathbf{4 d}$ & $4-\mathrm{OCH}_{3}$ & $2-\mathrm{F}$ & 1 & 2 & $1.021 \pm 0.13$ \\
$\mathbf{4 e}$ & $4-\mathrm{OCH}_{3}$ & $2-\mathrm{OCH}_{3}$ & 1 & 2 & $1.246 \pm 0.11$ \\
$\mathbf{4 f}$ & $4-\mathrm{OCH}_{3}$ & $4-\mathrm{OCH}_{3}$ & 1 & 2 & $1.144 \pm 0.06$ \\
$\mathbf{4 g}$ & $2-\mathrm{OCH}_{3}$ & $2-\mathrm{F}$ & 2 & 1 & $3.371 \pm 1.73$ \\
$\mathbf{4 h}$ & $2-\mathrm{OCH}_{3}$ & $2-\mathrm{F}$ & 2 & 2 & $1.339 \pm 1.02$ \\
$\mathbf{4 i}$ & $2-\mathrm{OCH}_{3}$ & $2-\mathrm{OCH}_{3}$ & 2 & 2 & $1.389 \pm 0.27$ \\
$\mathbf{4 j}$ & $2-\mathrm{OCH}_{3}$ & $-\mathrm{H}$ & 2 & 0 & $1.236 \pm 1.38$ \\
$\mathbf{4 k}$ & $2-\mathrm{OCH}_{3}$ & $2-\mathrm{OCH}_{3}$ & 2 & 1 & $1.44 \pm 0.05$ \\
\hline Acarbose & & & $\mathbf{0 . 3 8 2} \pm \mathbf{0 . 0 2 3}$ \\
\hline
\end{tabular}

${ }^{\mathrm{a}} \mathrm{SEM}=$ Standard error of the mean; values are expressed in mean \pm SEM for three parallel measurements.

\section{$\underline{\underline{\text { Table } 6}}$}

Table $\mathbf{6}$ Kinetic constants and inhibition constants for compound $\mathbf{4 b}$ against $\alpha$-glucosidase inhibition assay.

\begin{tabular}{lll}
\hline S. No. & Constants & Compound 4b \\
\hline \hline 1 & $\mathrm{IC}_{50}(\mathrm{mM}) \pm \mathrm{SEM}$ & $0.641 \pm 0.12$ \\
2 & $\mathrm{~K}_{\mathrm{m}}(\mathrm{mM})$ & 0.98 \\
3 & $\mathrm{~V}_{\max }(\mathrm{mM} / \mathrm{Sec})$ & $4.08 \times 10^{-3}$ \\
5 & $\mathrm{Inhibition} \mathrm{type}_{6}$ & competitive \\
6 & $K_{i}(\mathrm{M})$ & $1.5 \times 10^{-4}$ \\
\hline
\end{tabular}

$\underline{\underline{\text { Table } 7}}$

Table $\mathbf{7}$ Kinetic analysis of compound $\mathbf{4 c}$ against $\alpha$-glucosidase inhibition

\begin{tabular}{llllll}
\hline Measurement & $\mathbf{V}_{\max }(\mathbf{m M} / \mathbf{S e c})$ & $\mathbf{K m}(\mathbf{m M})$ & Inhibition type & $\boldsymbol{K i}(\mathbf{M})$ & $\boldsymbol{K i}^{\prime}(\mathbf{M})$ \\
\hline \hline No inhibitor & $5.55 \times 10^{-3}$ & 2.77 & & & \\
$0.096 \mathrm{mM}$ & $4.54 \times 10^{-3}$ & 4.16 & mixed-inhibition & $2.5 \times 10^{-4}$ & $4.0 \times 10^{-3}$ \\
$1.58 \mathrm{mM}$ & $3.84 \times 10^{-3}$ & 5.88 & & & \\
\hline
\end{tabular}

\section{$\underline{\text { Table } 8}$}

Table 8 Results of Urease inhibition assay for the Schiff base derivatives 7a-k

\begin{tabular}{lllll}
\hline Comp. & $\mathbf{R}$ & $\mathbf{Y}$ & $\mathbf{n}$ & $\begin{array}{l}\text { Urease inhibition assay } \\
\left(\mathbf{I C}_{\mathbf{5 0}} \pm{ }^{\mathbf{a}} \mathbf{S E M} \boldsymbol{\mu M}\right)\end{array}$ \\
\hline \hline 7a & 2-F & 2-Thiophenyl & 0 & $42.59 \pm 4.35$ \\
$\mathbf{7 b}$ & 2- $\mathrm{Br}$ & 2-Thiophenyl & 0 & $17.02 \pm 4.63$ \\
$\mathbf{7 c}$ & 2-OCH & 2-Thiophenyl & 0 & $39.30 \pm 5.03$ \\
$\mathbf{7 d}$ & 2-F & 2-Pyrroyl & 0 & $186.8 \pm 16.95$ \\
\hline
\end{tabular}




\begin{tabular}{lllll}
\hline $\mathbf{7 e}$ & 2-OCH & 2-Pyrroyl & 0 & $35.71 \pm 6.28$ \\
$\mathbf{7 f}$ & 3-F & 2-Ethylphenyl & 0 & $77.34 \pm 7.92$ \\
$\mathbf{7 g}$ & 3- $\mathrm{Br}$ & 2-Ethylphenyl & 0 & $8.02 \pm 0.59$ \\
$\mathbf{7 h}$ & 3-OCH & Benzyl & 0 & $20.29 \pm 2.76$ \\
$\mathbf{7 i}$ & 4-F & 2-Fluorophenyl & 1 & $159.15 \pm 21.38$ \\
$\mathbf{7 j}$ & 4-OCH & 2-Fluorophenyl & 0 & $25.45 \pm 3.09$ \\
$\mathbf{7 k}$ & 4-OCH & 2-Thiophenyl & 1 & $52.54 \pm 3.21$ \\
\hline${ }^{\mathbf{b}} \mathbf{T h i o u r e a}$ & & & & $\mathbf{2 0 . 9} \pm \mathbf{0 . 9 2}$ \\
\hline
\end{tabular}

${ }^{\mathrm{a}} \mathrm{SEM}=$ Standard error of the mean; values are expressed in mean \pm SEM for three parallel measurements ${ }^{\mathrm{b}}$ reference for urease inhibition assay 


\section{Graphical abstract}

\section{Facile synthesis, biological evaluation and molecular docking studies of novel substituted azole derivatives}

Muhammad Rafiq, Muhammad Saleem, Muhammad Hanif, Farukh Jabeen, Sung-Yum Seo, Sung Kwon Kang, Ki Hwan Lee

In this study, we synthesized the series of oxadiazole derivatives $\mathbf{4 a - k}$ as well as triazole Schiff base derivatives 7a-k. The synthesized compounds were evaluated for bioactivities, kinetic analysis and molecular modeling.

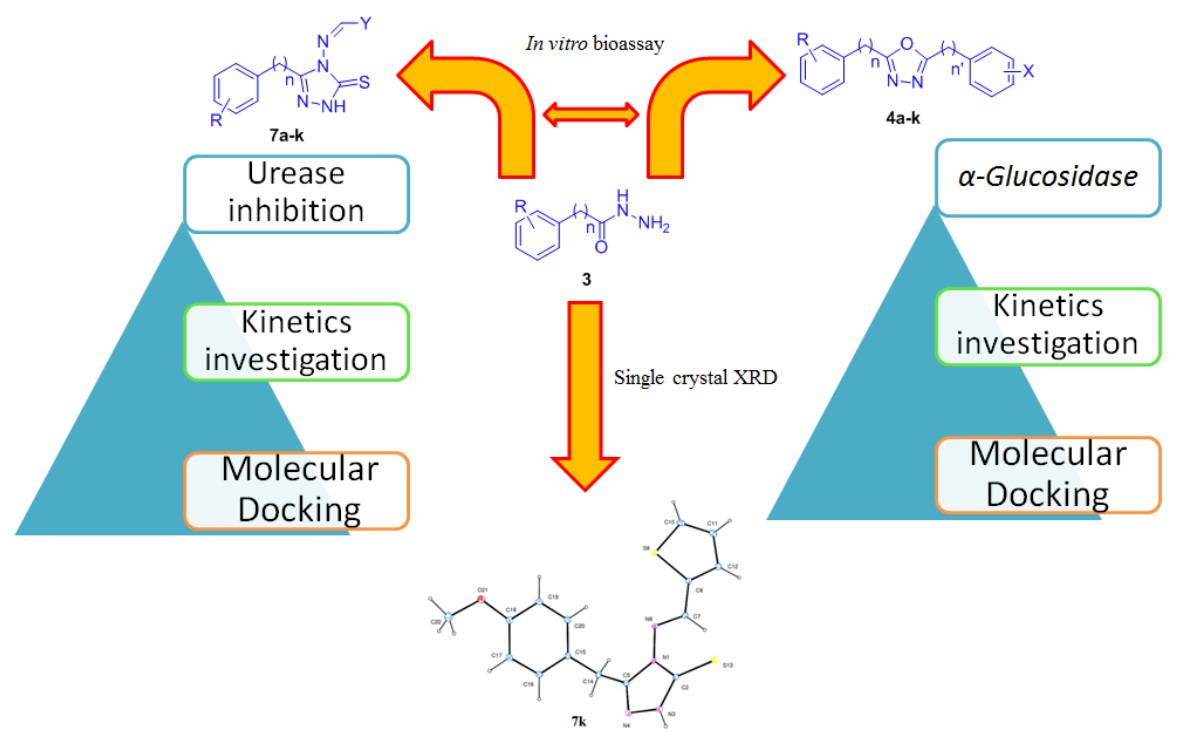

